\author{
Universidade de São Paulo \\ Faculdade de Odontologia de Ribeirão Preto \\ Departamento de Cirurgia e Traumatologia Buco-Maxilo-Facial e \\ Periodontia
}

Exposição a Fatores de Crescimento e Proteínas Típicos de Plasma Rico em Plaquetas Inibe a Formação de Nódulos de Mineralização de Culturas de Células Osteogênicas Crescidas Sobre Titânio

Marcos Andrade de Oliva 


\author{
Universidade de São Paulo \\ Faculdade de Odontologia de Ribeirão Preto \\ Departamento de Cirurgia e Traumatologia Buco-Maxilo-Facial e \\ Periodontia
}

\title{
Exposição a Fatores de Crescimento e Proteínas Típicos de Plasma Rico em Plaquetas Inibe a Formação de Nódulos de Mineralização de Culturas de Células Osteogênicas Crescidas Sobre Titânio
}

Dissertação apresentada à Faculdade de Odontologia de Ribeirão Preto da Universidade de São Paulo, como parte dos requisitos para obtenção do título de Mestre em Cirurgia e Traumatologia Buco-Maxilo-Facial.

Orientador: Paulo Tambasco de Oliveira 
OLIVA, Marcos Andrade de

Exposição a Fatores de Crescimento e Proteínas Típicos de Plasma Rico em Plaquetas Inibe a Formação de Nódulos de Mineralização de Culturas de Células Osteogênicas Crescidas Sobre Titânio. Ribeirão Preto, 2008.

69 p. : il. ; $30 \mathrm{~cm}$

Dissertação de Mestrado, apresentada à Faculdade de Odontologia de Ribeirão Preto/USP - Área de concentração: Cirurgia e Traumatologia Buco-MaxiloFacial - CTBMF

Orientador: De Oliveira, Paulo Tambasco

1. Titânio. 2. Fatores de crescimento. 3. Osteoblastos. 4. Cultura de células. 5. Proliferação celular. 6. Mineralização. 


\section{Dedicatória}

À minha família

e à minha noiva,

Leandra Monteiro de Paiva 


\section{Agradecimento Especial}

Ao meu orientador Prof. Dr. Paulo Tambasco de Oliveira

\section{Agradecimentos}

Aos Professores e amigos. Muito Obrigado.

Às instituições: Faculdade de Odontologia de Ribeirão Preto da Universidade de São Paulo (FORP-USP), Universidade de São Paulo (USP), Fundação de Amparo à Pesquisa do Estado de São Paulo (FAPESP) e Université de Montréal (UdeM, Montreal, QC, Canadá); 


\section{SUMÁRIO}

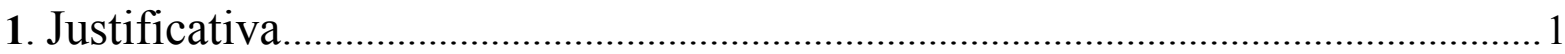

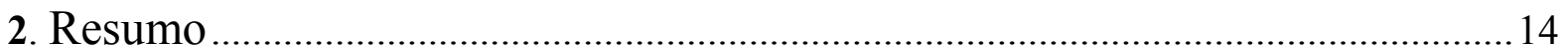

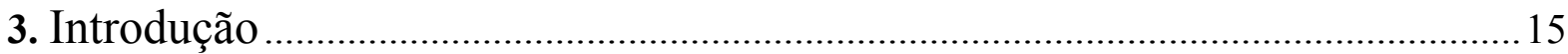

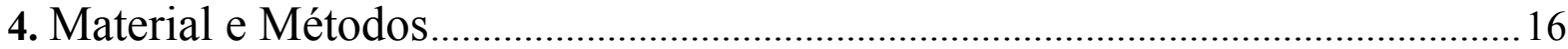

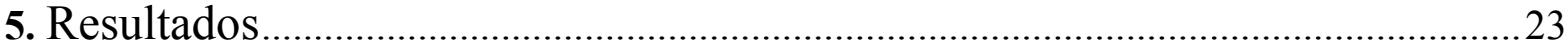

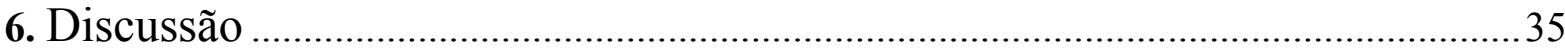

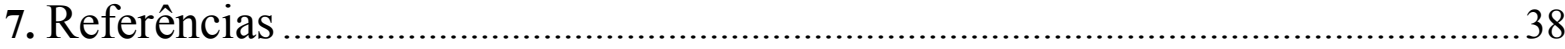

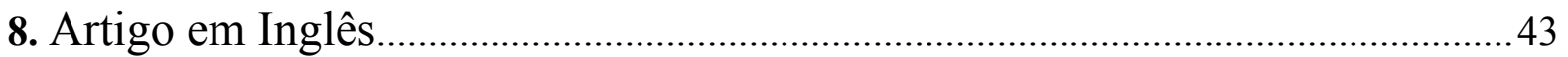




\section{JUSTIFICATIVA}

Um dos objetivos principais das pesquisas com biomateriais tem sido o desenvolvimento de materiais para implantação que favoreçam o reparo rápido, controlado e previsível dos tecidos biológicos interfaciais. Para isso, não só se desenvolvem novos materiais, como também se modificam aqueles tradicionalmente utilizados em diferentes aplicações clínicas. Com efeito, vários aspectos físicos, químicos e topográficos da superfície dos materiais têm sido modificados visando ao desenvolvimento de interface implante-tecido com características adequadas a uma determinada aplicação (Brunski et al., 2000). Essa estratégia baseia-se no fato de a superfície do material estar em íntimo contato com o(s) tecido(s) biológico(s) no sítio de implantação, o que é crítico para a determinação de sua biocompatibilidade (Nanci et al., 1998).

Métodos bioquímicos para tratamento de superfícies constituem-se em uma alternativa às modificações mencionadas acima, ou até mesmo se somam a elas. O objetivo da modificação bioquímica é o de imobilizar proteínas, enzimas ou peptídios bioativos em superfícies de biomateriais com o intuito de induzir respostas celulares e teciduais específicas, por meio da liberação dessas moléculas diretamente para a região interfacial (Puleo \& Nanci, 1999).

$\mathrm{Na}$ área de desenvolvimento de novas superfícies metálicas para implantação no tecido ósseo, observa-se crescente interesse na utilização de moléculas bioativas que possuem efeitos conhecidos na formação óssea (Puleo \& Nanci, 1999). Como o desenvolvimento da interface osso-implante apresenta diversas semelhanças com processos que ocorrem nas interfaces ósseas naturais e em sítios de reparo de tecidos mineralizados, moléculas envolvidas nesses processos seriam também potencialmente capazes de influenciar a integração de biomateriais (Nanci et al., 1998). Entre os diferentes fatores de crescimento (GFs, da sigla em Inglês) e proteínas que constituem a matriz extracelular do tecido ósseo (Robey, 1996; Young, 2003; Linkhart et al., 1996; Schliephake, 2002), aqueles presentes na interface osso-implante poderiam, assim, 
representar estratégias adequadas para o revestimento da superfície de biomateriais com a finalidade de se controlar e promover a osteogênese (Puleo \& Nanci, 1999).

Por meio de técnicas de biologia molecular, diversos GFs têm sido clonados e expressos por recombinação, facilitando assim a avaliação de seus efeitos em diferentes sistemas biológicos. Isso tem resultado na publicação de numerosos estudos sobre os efeitos individuais de diferentes GFs na biologia do tecido ósseo (revisado por Linkhart et al., 1996; Schliephake, 2002). Seus efeitos estimuladores no processo de osteogênese podem ser: 1) quimiotático (atribuído, p.e., aos fatores de crescimento derivado de plaqueta-BB, PDGF-BB, e transformante- $\beta 1$, TGF- $\beta 1$, que estimulam a migração de células osteogênicas); 2) mitogênico (p.e., fatores de crescimento insulina-símile-1, IGF-1, de fibroblasto-2, FGF-2, de tecido conjuntivo, CTGF, PDGF-BB e TGF- $\beta 1$ ); 3 ) de aumento de atividade de síntese celular (p.e., TGF- $\beta 1$, que acentua a síntese de colágeno, e IGF-1, que estimula a síntese de proteínas da matriz óssea in vitro), e 4) de indução para a diferenciação osteoblástica (p.e., proteínas morfogenéticas ósseas, BMPs, fatores de crescimento e diferenciação, como o GDF-5, e CTGF) (Canalis, 1981; Mohan \& Baylink, 1991; Kawai et al., 1993; Ripamonti et al., 1993; Lind, 1996; Linkhart et al., 1996; Martin et al., 1997; Lind, 1998; Brunski et al., 2000; Conover, 2000; Gurlek \& Kumar, 2001; Fiedler et al., 2002; Schliephake, 2002; Fischer et al., 2003; Lucarelli et al., 2003; Ortiz et al., 2003; Safadi et al., 2003; Shimaoka et al., 2004; Luo et al., 2004; Arosarena \& Puleo 2007; Elsalanty et al., 2008.

Observa-se, também, que os efeitos biológicos causados pelos GFs dependem de diversos parâmetros, os quais incluem: (1) concentração de GFs na matriz extracelular, (2) tempo e duração da exposição, (3) tipo de célula alvo e seu estágio de diferenciação, (4) a expressão de receptores celulares específicos, e (5) a presença de outros GFs, os quais podem promover efeitos sinérgicos ou antagônicos (Giannobile et al., 1997; Strayhorn et al., 1999; Schmidmaier et al., 2003; Chaudhary et al., 2004; Huang et al., 2005; discutido em Ranly et al., 2007). Por 
exemplo, em relação ao TGF- $\beta$, seu efeito mitogênico ocorre apenas em algumas espécies animais, como o rato e o homem, enquanto que no camundongo sua ação resulta em inibição da proliferação celular (revisado por Lind, 1996). Há também controvérsias quanto à influência que o TGF- $\beta$ exerce no processo de diferenciação osteoblástica em diferentes modelos experimentais. Apesar de estimular a síntese de matriz colágena, parece ser de consenso que o TGF- $\beta$ tem ação inibidora na síntese de proteínas características do fenótipo osteoblástico, como a fosfatase alcalina e a osteocalcina (revisado por Lind, 1996; Gurlek \& Kumar, 2001). Por fim, uma das importantes limitações de estudos sobre os efeitos isolados de GFs é a impossibilidade de avaliar fenômenos biológicos mais complexos, como o processo de reparação tecidual. Com efeito, a ação de cada fator individualmente ocasiona deficiências na regeneração tecidual (revisado por Anitua et al., 2007).

Os processos de formação e reparo ósseos resultam de uma complexa seqüência de eventos celulares e teciduais, envolvendo numerosos GFs, citocinas e proteínas da matriz extracelular. Evidências para a ocorrência de complexas interações entre GFs na osteogênese fundamentam-se no fato de: 1) diferentes GFs estarem incorporados à matriz óssea em altas concentrações; 2) células da linhagem osteoblástica secretarem diversos GFs, e 3) genes que codificam GFs e seus produtos serem expressos durante o reparo ósseo (revisado por Giannobile et al., 1997; Cho et al., 2002; Lucarelli et al., 2003; Raiche \& Puleo, 2004; Li et al., 2005). Essas complexas interações podem resultar em: 1) sinergismo, quando o efeito resultante é maior que a soma dos efeitos individuais de cada fator (p.e., associação de células da medula óssea humana, BMP-4 e fator de crescimento endotelial vascular, VEGF, resulta em aumento significativo na quantidade de osso formado no sítio de implantação quando comparada à ação unitária ou a combinações de dois desses fatores; Huang et al., 2005); 2) soma dos efeitos individuais de cada fator (Giannobile et al., 1997), e 3) antagonismo, quando o efeito final é oposto àquele proporcionado pelos GFs individualmente (p.e., IGF-1 e TGF- $\beta$ são mitogênicos em diversos 
modelos experimentais, mas quando associados, podem promover a redução da proliferação osteoblástica in vitro; Schmidmaier et al., 2003; associação de FGF-2 e BMP-7 resulta em significativa redução da diferenciação osteoblástica induzida por BMP-7; Chaudhary et al., 2004).

Com base em evidências como as descritas acima, estratégias para o desenvolvimento de terapia gênica e de terapia com proteínas incluem a expressão ou disponibilização simultânea e/ou seqüencial de diversos GFs e proteínas, na tentativa de simular eventos de expressão gênica e de RNAm, de síntese e secreção de proteínas que ocorrem complexa e seqüencialmente durante o processo de reparo ósseo (Franceschi et al., 2004; Kofron et al., 2004).

Uma das terapias mais conhecidas para a disponibilização de GFs em defeitos ósseos é a aplicação de plasma rico em plaquetas (PRP), definido como preparações de concentrados de plaquetas no plasma (Marx et al., 1998; Dugrillon et al., 2002; Marx, 2004; Anitua et al., 2007; Nikolidakis et al., 2008). Essa terapia se baseia no fato de as plaquetas estarem entre os primeiros elementos a atuar em sítios de reparo tecidual (Marx et al., 1998) e, associadas ao plasma, interagir com superfícies de biomateriais no período pós-implantação (Nygren et al., 1997; Park \& Davies, 2000; Park et al., 2001; Soffer et al., 2003). Esses corpúsculos contêm quantidade expressiva de GFs que são ativamente secretados, entre os quais se destacam PDGF, TGF- $\beta$ e VEGF, em um ambiente com proteínas do plasma e numerosas moléculas da matriz extracelular (Gruber et al., 2003; Lucarelli et al., 2003; Kawase et al., 2005; Graziani et al., 2006; van den Dolder et al., 2006). As múltiplas e complexas associações entre GFs secretados por plaquetas e proteínas plasmáticas afetam as interações célula-matriz extracelular-superfície do material, as quais, por sua vez, definem os eventos subseqüentes do processo de formação tecidual. Assim, tem-se observado nos últimos anos um crescente interesse no desenvolvimento de métodos para obtenção de PRP, com o objetivo de favorecer o reparo tecidual em diferentes aplicações clínicas (Marx et al., 1998; Landesberg et al., 2000; Dugrillon et al., 2002). 
Os resultados de estudos realizados para investigar o efeito do PRP na regeneração óssea são controversos. Alguns autores reportaram efeito positivo na osteogênese (Merkx et al., 2004; Ferreira et al., 2005; Hibi et al., 2006; Graziani et al., 2006; Gerard et al., 2006; Nikolidakis et al., 2008), enquanto outros não observaram qualquer efeito em sua utilização (Sarkar et al., 2006; Mooren et al., 2007; Roussy et al., 2007). Por outro lado, inibição da indução para formação óssea tem sido observado na associação do PRP com GFs osteogênicos (Gruber et al., 2006; Thorwarth et al., 2006; Ranly et al., 2007). Esses resultados controversos têm sido atribuídos a diferentes aspectos do PRP, entre os quais: 1) variações intra e inter-espécies na proporção relativa dos componentes (Lacoste et al., 2003; van den Dolder et al., 2006; Ranly et al., 2007; Roussy et al., 2007); 2) diferenças no protocolo de preparação (Anitua et al., 2007), e 3) variações na densidade/concentração de plaquetas (Weibrich et al., 2004; Choi et al., 2005; Graziani et al., 2006; Ranly et al., 2007; Tomoyasu et al., 2007; discutido por Mooren et al., 2007). É importante ressaltar o crescente número de publicações que mostram que a associação do PRP a enxertos autógenos, alógenos ou aloplásticos não estimula a formação óssea (Mooren et al., 2007) ou até mesmo inibe os fenômenos osseoindutivos, como no caso da associação com matriz óssea desmineralizado (Ranly et al., 2007; Ranly et al., 2005)

Sendo assim, justifica-se o desenvolvimento de modelos experimentais visando a evitar as variações inerentes ao PRP, elaborando formulações contendo seus principais componentes protéicos, em ambientes controlados, com o objetivo principal de avaliar seus efeitos no processo de osteogênese in vitro principalmente sobre superfícies de titânio, reconhecidamente um material biocompatível e que permite o crescimento ósseo. 


\section{REFERÊNCIAS}

ANITUA, E.; SANCHEZ, M.; ORIVE, G.; ANDÍA, I. The potential impacto $f$ the preparation rich in growth factors in different medical fields. Biomaterials, v.28, p.4551-60, 2007

AROSARENA, O.A.; PULEO, D. In vitro effects of combined and sequential bone morphogenetic protein administration. Arch Facial Plast Surg; v.9, n.4, p.242-7, July-Aug. 2007.

BRUNSKI, J.B.; PULEO, D.A.; NANCI, A. Biomaterials and biomechanics of oral and maxillofacial implants: current status and future developments. Int J Oral Maxillofac Implants, v.15, n.1, p.15-46, Jan.-Feb. 2000.

CANALIS, E. Effect of platelet-derived growth factor on DNA and protein synthesis in cultured rat calvaria. Metabolism, v.30, n.10, p.970-5, Oct. 1981.

CHAUDHARY, L.R.; HOFMEISTER, A.M.; HRUSKA, K.A. Differentia growth factor control of bone formation through osteoprogenitor differentiation. Bone, v.34, n.3, p.402-11, Mar. 2004.

CHO, T.J.; GERSTENFELD, L.C.; EINHORN, T.A. Differential temporal expression of members of the transforming growth factor beta superfamily during murine fracture healing. J Bone Miner Res, v.17, n.3, p.513-20, Mar. 2002.

CHOI, B.H.; ZHU, S.J.; KIM, B.Y.; HUH, J.Y.; LEE, S.H.; JUNG, J.H. Effect of platelet-rich plasma (PRP) concentration on the viability and proliferation of alveolar bone cells: an in vitro study. Int J Oral Maxillofac Surg, v.34, n.4, p.420-4, June 2005.

CONOVER, C.A. In vitro studies of insulin-like growth factor I and bone. Growth Horm IGF Res, v.10, Suppl B, p.S107-10, Apr. 2000.

DUGRILlON, A.; EICHLER, H.; KERN, S.; KLUTER, H. Autologous concentrated plateletrich plasma (cPRP) for local application in bone regeneration. Int J Oral Maxillofac Surg, v.31, n.6, p.615-9, Dec. 2002.

ELSALANTY, M.E.; POR, Y.C.; GENECOV, D.G.; SALYER, K.E.; WANG, Q.; BARCELO, C.R.; TROXLER, K.; GENDLER, E.; OPPERMAN, L.A. Recombinant human BMP-2 enhances the effects of materials used for reconstruction of large cranial defects. J Oral Maxillofac Surg, v.66, n.2, p. 277-85, Feb. 2008.

FERREIRA, C.F.; GOMES, M.C.C.; FILHO, J.S.; GRANJEIRO, J.M.; SIMÕES, C.M.O.; MAGINI, R.S. Platelet-rich plasma influence on human osteoblasts growth. Clin Oral Implants Res, v.16, n.4, p.456-60, Aug. 2005. 
FIEDLER, J.; RÖDERER, G.; GÜNTHER, K.P.; BRENNER, R.E. BMP-2, BMP-4, and PDGFbb stimulate chemotactic migration of primary human mesenchymal progenitor cells. J Cell Biochem, v.87, n.3, p.305-12, 2002

FISCHER, U.; HEMPEL, U.; BECKER, D.; BIERBAUM, S.; SCHARNWEBER, D.; WORCH, H.; WENZEL, K.W. Transforming growth factor beta1 immobilized adsorptively on Ti6A14V and collagen type I coated Ti6Al4V maintains its biological activity. Biomaterials, v.24, n.15, p.2631-41, July 2003.

FRANCESCHI, R.T.; YANG, S.; RUTHERFORD, R.B.; KREBSBACH, P.H.; ZHAO, M.; WANG, D. Gene therapy approaches for bone regeneration. Cells Tissues Organs, v.176, n.1-3, p.95-108, 2004.

GERARD, D.; CARLSON, E.R.; GOTCHER, J.E.; JACOBS, M. Effects of platelet-rich plasma on the healing of autologous bone grafted mandibular defects in dogs. J Oral Maxillofac Surg, v.64, n.3, p.443-51, Mar. 2006.

GIANNOBILE, W.V.; WHITSON, S.W.; LYNCH, S.E. Non-coordinate control of bone formation displayed by growth factor combinations with IGF-I. J Dent Res, v.76, n.9, p.1569-78, Sep. 1997.

GRAZIANI, F.; IVANOVSKI, S.; CEI, S.; DUCCI, F.; TONETTI, M.; GABRIELE, M. The in vitro effect of different PRP concentrations on osteoblasts and fibroblasts. Clin Oral Implants Res, v.17, n.2, p.212-9, Apr. 2006.

GRUBER, R.; KANDLER, B.; FISCHER, M.B.; WATZEK, G. Osteogenic differentiation induced by bone morphogenetic proteins can be suppressed by platelet-released supernatant in vitro. Clin Oral Implants Res, v.17, n.2, p.188-93, Apr. 2006.

GRUBER, R.; KARRETH, F.; FROMMLET, F.; FISCHER, M.B.; WATZEK, G. Platelets are mitogenic for periosteum-derived cells. J Orthop Res, v.21, n.5, p.941-8, Sep. 2003.

GURLEK, A.; KUMAR, R. Regulation of osteoblast growth by interactions between transforming growth factor-beta and 1alpha,25-dihydroxyvitamin D3. Crit Rev Eukaryot Gene Expr, v.11, n.4, p.299-317, 2001.

HIBI, H.; YAMADA, Y.; UEDA, M.; ENDO ,Y. Alveolar cleft osteoplasty using tissueengineered osteogenic material. Int J Oral Maxillofac Surg, v.35, n.6, p.551-5, June 2006.

HUANG, Y.C.; KAIGLER, D.; RICE, K.G.; KREBSBACH, P.H.; MOONEY, D.J. Combined angiogenic and osteogenic factor delivery enhances bone marrow stromal cell-driven bone regeneration. J Bone Miner Res, v.20, n.5, p.848-57, May 2005. 
KAWAI, T.; MIEKI, A.; OHNO, Y.; UMEMURA, M.; KATAOKA, H.; KURITA, S.; KOIE, M.; JINDE, T.; HASEGAWA, J.; URIST, M.R. Osteoinductive activity of composites of bone morphogenetic protein and pure titanium. Clin Orthop, n.290, p.296-305, May 1993.

KAWASE, T.; OKUDA, K.; SAITO, Y.; YOSHIE, H. In vitro evidence that the biological effects of platelet-rich plasma on periodontal ligament cells is not mediated solely by constituent transforming-growth factor-beta or platelet-derived growth factor. $\mathbf{J}$ Periodontol, v.76, n.5, p.760-7, May 2005.

KOFRON, M.D.; LI, X.; LAURENCIN, C.T. Protein- and gene-based tissue engineering in bone repair. Curr Opin Biotechnol, v.15, n.5, p.399-405, Oct. 2004.

LACOSTE, E.; MARTINEAU, I.; GAGNON, G. Platelet concentrates: effects of calcium and thrombin on endothelial cell proliferation and growth factor release. J Periodontol, v.74, n.10, p.1498-507, Oct. 2003.

LANDESBERG, R.; ROY, M.; GLICKMAN, R.S. Quantification of growth factor levels using a simplified method of platelet-rich plasma gel preparation. J Oral Maxillofac Surg, v.58, n.3, p.297-300, Mar. 2000.

LI, X.; QUIGG, R.J.; ZHOU, J.; RYABY, J.T.; WANG, H. Early signals for fracture healing. J Cell Biochem, v.95, n.1, p.189-205, May 2005.

LIND, M. Growth factors stimulation of bone healing. Effects on osteoblasts, osteomies, and implants fixation. Acta Orthop Scand, v.283, p.2-37, Oct. 1998. Supplement.

LIND, M. Growth factors: possible new clinical tools. A review. Acta Orthop Scand, v.67, n.4, p.407-17, Aug. 1996.

LINKHART, T.A.; MOHAN, S.; BAYLINK, D.J. Growth factors for bone growth and repair: IGF, TGF beta and BMP. Bone, v.19, Suppl 1, p.1S-12S, July 1996.

LUCARELLI, E.; BECCHERONI, A.; DONATI, D.; SANGIORGI, L.; CENACCHI, A.; DEL VENTO, A.M.; MEOTTI, C.; BERTOJA, A.Z.; GIARDINO, R.; FORNASARI, P.M.; MERCURI, M.; PICCI, P. Platelet-derived growth factors enhance proliferation of human stromal stem cells. Biomaterials, v.24, n.18, p.3095-100, Aug. 2003.

LUO, Q.; KANG, Q.; SI, W.; JIANG, W.; PARK, J.K.; PENG, Y.; LI, X.; LUU, H.H.; LUO, J.; MONTAG, A.G.; HAYDON, R.C.; HE, T.C. Connective tissue growth factor (CTGF) is regulated by Wnt and bone morphogenetic proteins signaling in osteoblast differentiation of mesenchymal stem cells. J Biol Chem, v.279, n.53, p.55958-68, Dec. 2004.

MARTIN, I.; MURAGLIA, A.; CAMPANILE, G.; CANCEDDA, R.; QUARTO, R. Fibroblast growth factor-2 supports ex vivo expansion and maintenance of osteogenic precursors from human bone marrow. Endocrinology, v.138, n.10, p.4456-62, Oct. 1997. 
MARX, R.E. Platelet-rich plasma: evidence to support its use. J Oral Maxillofac Surg, v.62, n.8, p.1046-8, Aug. 2004.

MARX, R.E.; CARLSON, E.R.; EICHSTAEDT, R.M.; SCHIMMELE, S.R.; STRAUSS, J.E.; GEORGEFF, K.R. Platelet-rich plasma: Growth factor enhancement for bone grafts. Oral Surg Oral Med Oral Pathol Oral Radiol Endod, v.85, n.6, p.638-46, June 1998.

MERKX, M.A.; FENNIS, J.P.; VERHAGEN, C.M.; STOELINGA, P.J. Reconstruction of the mandible using preshaped $2.3 \mathrm{~mm}$ titanium plates, autogenous particulate cortico-cancellous bone grafts and platelet rich plasma: a report on eight patients. Int J Oral Maxillofac Surg, v.33, n.8, p.733-9, Dec. 2004.

MOHAN, S.; BAYLINK, D.J. Bone growth factors. Clin Orthop, n.263, p.30-48, Feb. 1991.

MOOREN, R.E.; MERKX, M.A.; BRONKHORST, E.M.; JANSEN, J.A.; STOELINGA, P.J. The effect of platelet-rich plasma on early and late bone healing: an experimental study in goats. Int J Oral Maxillofac Surg, v.36, n.7, p.626-31, July 2007.

NANCI, A.; MCKEE, M.D.; ZALZAL, S.; SAKKAL, S. Ultrastructural and immunocytochemical analysis of the tissue response to metal implants in the rat tibia. In: DAVIDOVITCH, Z.; MAH, J. eds. Biological mechanisms of tooth eruption, resorption and replacement by implants. Boston: Harvard Society for the Advancement of Orthodontics, 1998. p.487-500.

NIKOLIDAKIS, D.; VAN DEN DOLDER, J.; WOLKE, J.G.; JANSEN, J.A. Effect of plateletrich plasma on the early bone formation around Ca-P-coated and non-coated oral implants in cortical bone. Clin Oral Implants Res, v.19, n.2, p.207-13, Feb. 2008.

NYGREN, H.; ERIKSSON, C.; LAUSMAA, J. Adhesion and activation of platelets and polymorphonuclear granulocyte cells at TiO2 surfaces. J Lab Clin Med, v.129, n.1, p.3546, Jan. 1997.

ORTIZ, C.O.; CHEN, B.K.; BALE, L.K.; OVERGAARD, M.T.; OXVIG, C.; CONOVER, C.A. Transforming growth factor-beta regulation of the insulin-like growth factor binding protein4 protease system in cultured human osteoblasts. J Bone Miner Res, v.18, n.6, p.1066-72, June 2003.

PARK, J.Y.; DAVIES, J.E. Red blood cell and platelet interactions with titanium implant surfaces. Clin Oral Implants Res, v.11, n.6, p.530-9, Dec. 2000.

PARK, J.Y.; GEMMELL, C.H.; DAVIES, J.E. Platelet interactions with titanium: modulation of platelet activity by surface topography. Biomaterials, v.22, n.19, p.2671-82, Oct. 2001.

PULEO, D.A.; NANCI, A. Understanding and controlling the bone-implant interface. Biomaterials, v.20, n.23-24, p.2311-21, Dec. 1999. 
RAICHE, A.T.; PULEO, D.A. In vitro effects of combined and sequential delivery of two bone growth factors. Biomaterials, v.5, n.4, p.677-85, Feb. 2004.

RANLY, D.M.; LOHMANN, C.H.; ANDREACCHIO, D.; BOYAN, B.D.; SCHWARTZ, Z. Platelet-rich plasma inhibits demineralized bone matrix-induced bone formation in nude mice. J Bone Joint Surg Am, v.89, n.1, p.139-47, Jan. 2007.

RANLY, D.M.; MCMILLAN, J.; KELLER, T.; LOHMANN, C.H.; MEUNCH, T.; COCHRAN, D.L.; SCHWARTZ, Z.; BOYAN, B.D. Platelet-derived growth factor inhibits demineralized bone matrix-induced intramuscular cartilage and bone formation. A study of immunocompromised mice. J Bone Joint Surg Am, v.87, n.9, p.2052-64, Sep. 2005.

RIPAMONTI, U.; YEATES, L.; VAN DEN HEEVER, B. Initiation of heterotopic osteogenesis in primates after chromatographic adsorption of osteogenin, a bone morphogenetic protein, onto porous hydroxyapatite. Biochem Biophys Res Commun, v.193, n.2, p.509-17, June 1993.

ROBEY, P.G. Vertebrate mineralized matrix proteins: structure and function. Connect Tissue Res, v.35, n.1-4, p.131-6, 1996.

ROUSSY, Y.; BERTRAND DUCHESNE, M.P.; GAGNON, G. Activation of human plateletrich plasmas: effect on growth factors release, cell division and in vivo bone formation. Clin Oral Implants Res, v.18, n.5, p.639-48, Oct. 2007.

SAFADI, F.F.; XU, J.; SMOCK, S.L.; KANAAN, R.A.; SELIM, A.H.; ODGREN, P.R.; MARKS JR, S.C.; OWEN, T.A.; POPOFF, S.N. Expression of connective tissue growth factor in bone: its role in osteoblast proliferation and differentiation in vitro and bone formation in vivo. J Cell Physiol, v.196, n.1, p.51-62, July 2003.

SARKAR, M.R.; AUGAT, P.; SHEFELBINE, S.J.; SCHORLEMMER, S.; HUBER-LANG, M.; CLAES, L.; KINZL, L.; IGNATIUS, A. Bone formation in a long bone defect model using a platelet-rich plasma-loaded collagen scaffold. Biomaterials, v.27, n.9, p.1817-23, Mar. 2006.

SCHLIEPHAKE, H. Bone growth factors in maxillofacial skeletal reconstruction. Int $\mathbf{J}$ Oral Maxillofac Surg, v.31, n.5, p.469-84, Oct. 2002.

SCHMIDMAIER, G.; WILDEMANN, B.; LUBBERSTEDT, M.; HAAS, N.P.; RASCHKE, M. IGF-I and TGF-beta 1 incorporated in a poly(D,L-lactide) implant coating stimulates osteoblast differentiation and collagen-1 production but reduces osteoblast proliferation in cell culture. J Biomed Mater Res, v.65B, n.1, p.157-62, Apr. 2003.

SHIMAOKA, H.; DOHI, Y.; OHGUSHI, H.; IKEUCHI, M.; OKAMOTO, M.; KUDO, A.; KIRITA, T.; YONEMASU, K. Recombinant growth/differentiation factor-5 (GDF-5) 
stimulates osteogenic differentiation of marrow mesenchymal stem cells in porous hydroxyapatite ceramic. J Biomed Mater Res A, v.68, n.1, p.168-76, Jan. 2004.

SOFFER, E.; OUHAYOUN, J.P.; ANAGNOSTOU, F. Fibrin sealants and platelet preparations in bone and periodontal healing. Oral Surg Oral Med Oral Pathol Oral Radiol Endod, v.95, n.5, p.521-8, May 2003.

STRAYHORN, C.L.; GARRETT, J.S.; DUNN, R.L.; BENEDICT, J.J.; SOMERMAN, M.J. Growth factors regulate expression of osteoblast-associated genes. J Periodontol, v.70, n.11, p.1345-54, Nov. 1999.

THORWARTH, M.; WEHRHAN, F.; SCHULTZE-MOSGAU, S.; WILTFANG, J.; SCHLEGEL, K.A. PRP modulates expression of bone matrix proteins in vivo without longterm effects on bone formation. Bone, v.38, n.1, p.30-40, Jan. 2006.

TOMOYASU, A.; HIGASHIO, K.; KANOMATA, K.; GOTO, M.; KODAIRA, K.; SERIZAWA, H.; SUDA, T.; NAKAMURA, A.; NOJIMA, J.; FUKUDA, T.; KATAGIRI, T. Platelet-rich plasma stimulates osteoblastic differentiation in the presence of BMPs. Biochem Biophys Res Commun, v.361, n.1, p.62-7, Sep. 2007.

VAN DEN DOLDER, J.; MOOREN, R.; VLOON, A.P.; STOELINGA, P.J.; JANSEN, J.A. Platelet-rich plasma: quantification of growth factor levels and the effect on growth and differentiation of rat bone marrow cells. Tissue Eng, v.12, p.3067-73, 2006.

WEIBRICH, G.; HANSEN, T.; KLEIS, W.; BUCH, R.; HITZLER, W.E. Effect of platelet concentration in platelet-rich plasma on peri-implant bone regeneration. Bone, v.34, n.4, p.665-71, Apr. 2004.

WORAPAMORN, W.; TAM, S.P.; LI, H.; HAASE, H.R.; BARTOLD, P.M. Cytokine regulation of syndecan-1 and -2 gene expression in human periodontal fibroblasts and osteoblasts. J Periodontal Res, v.37, n.4, p.273-8, Aug. 2002.

YOUNG, M.F. Bone matrix proteins: their function, regulation, and relationship to osteoporosis. Osteoporos Int, v.14, Suppl 3, p.S35-42, 2003. 


\section{Artigo em Português *}

*Este artigo foi escrito de acordo com as normas do Journal of Biomedical Materials Research Part A. 
Exposição a Fatores de Crescimento e Proteínas Típicos de Plasma Rico em Plaquetas Inibe a Formação de Nódulos de Mineralização de Culturas de Células Osteogênicas Crescidas Sobre Titânio

Marcos Andrade de Oliva ${ }^{1}$, William Marcatti Amarú Maximiano ${ }^{1}$, Larissa Moreira Spínola de Castro ${ }^{1}$, Paulo Eliandro da Silva Junior ${ }^{1}$, Roger Rodrigo Fernandes ${ }^{1}$, Pietro Ciancaglini ${ }^{2}$, Márcio Mateus Beloti ${ }^{1}$, Antonio Nanci $^{3}$, Adalberto Luiz Rosa ${ }^{1}$, Paulo Tambasco de Oliveira ${ }^{1}$

1 Laboratório de Cultura de Células da Faculdade de Odontologia de Ribeirão Preto, Universidade de São Paulo, Av. do Café, s/n, CEP 14040-904, Ribeirão Preto, SP, Brasil

${ }^{2}$ Departamento de Química, Faculdade de Filosofia, Ciências e Letras de Ribeirão Preto, Universidade de São Paulo, Ribeirão Preto, SP, Brasil

${ }^{3}$ Laboratory for the Study of Calcified Tissues and Biomaterials, Faculté de Médecine Dentaire, Université de Montréal, P.O. Box 6128, Station Centre-Ville, Montréal, QC H3C 3J7, Canada

*Endereço para correspondência: Prof. Dr. Paulo Tambasco de Oliveira, Departamento de Morfologia, Estomatologia e Fisiologia, Faculdade de Odontologia de Ribeirão Preto, Universidade de São Paulo, Av. do Café, s/n - 14040-940 - Ribeirão Preto, SP, Brasil. Tel. + 55 16 3602-3978 Fax: + 5516 3633-0999. E-mail: tambasco@usp.br 


\section{RESUMO}

Apesar da ampla aplicação clínica de plasma rico em plaquetas (PRP), a sua eficácia no reparo de defeitos ósseos e na osseointegração de implantes metálicos continua sendo questionada. Em vista disso, objetivo do presente estudo foi avaliar os efeitos de um coquetel contendo os principais fatores de crescimento (GFs) e proteínas de PRP no desenvolvimento do fenótipo osteogênico in vitro sobre titânio (Ti). O coquetel referido continha PDGF-BB, TGF- $\beta 1$, TGF$\beta 2$, albumina, fibronectina e trombospondina. Células da linhagem osteoblástica foram obtidas por digestão enzimática de osso alveolar humano e cultivadas sob condições osteogênicas convencionais até a subconfluência, sendo, em seguida, subcultivadas sobre superfície de Ti. As subculturas foram expostas durante os 7 primeiros dias a meio osteogênico, suplementado com GFs e proteínas, e apenas ao meio osteogênico nos 7 dias subseqüentes. Os grupos controles foram expostos apenas ao meio osteogênico. Nos experimentos dose-resposta foram utilizadas culturas primárias de calvária de ratos, as quais foram expostas ao coquetel de GFs e proteínas e às suas diluições de 1:10 e 1:100. Culturas derivadas de osso alveolar humano expostas ao coquetel de GFs e proteínas apresentaram: aumento significativo do número de células a partir do dia 4 e da proliferação celular em 1 e 4 dias; redução significativa nos níveis de atividade de fosfatase alcalina (ALP) em 4, 7 e 10 dias e ausência de marcação com vermelho de Alizarina em 14 dias. Apesar de as diluições 1:10 e 1:100 restaurarem a atividade proliferativa das culturas aos níveis controles, formações de matriz calcificada foram observadas apenas na diluição 1:100. Os resultados do presente trabalho mostram que o coquetel de GFs e proteínas inibe o desenvolvimento do fenótipo osteogênico de culturas de células osteoblásticas humanas e de ratos crescidas sobre Ti.

Palavras-Chaves: Titânio, Fatores de crescimento, Osteoblastos, Cultura de células, Proliferação celular, Mineralização. 


\section{INTRODUÇÃO}

A capacidade de induzir formação óssea na superfície de implantes é de grande importância para melhorar o reparo tecidual, aumentar a estabilidade e, dessa forma, antecipar a aplicação de carga funcional. Com esse intuito, diversas terapias regenerativas com fatores de crescimento (GFs) têm sido aplicadas para promover e, em alguns casos até mesmo induzir, à neoformação óssea em sítios de fraturas e superfícies de implantes metálicos. ${ }^{1-4} \mathrm{Na}$ área da implantologia, estudos têm mostrado a melhora em parâmetros da osseointegração através da utilização de proteínas morfogenéticas ósseas recombinantes humanas (rhBMPs) ou fator de crescimento transformante $\beta$ recombinante humano (rhTGF- $\beta$ ). ${ }^{1,5-9}$

Durante o processo de reparo ósseo, as células estão expostas simultaneamente a diversos GFs, especialmente na fase inicial, quando plaquetas do coágulo sanguíneo liberam seus constituintes. ${ }^{10}$ Com esse objetivo, concentrados de plaquetas no plasma têm sido utilizados para favorecer o reparo em defeitos ósseos. ${ }^{11-13}$ Essas preparações, também conhecidas como plasma rico em plaquetas (PRP), apresentam grande quantidade de fator de crescimento derivado de plaquetas (PDGF), fator de crescimento transformante $\beta$ (TGF- $\beta$ ) e diversas proteínas plasmáticas. ${ }^{14-20}$ Embora trabalhos clínicos tenham apresentado efeito positivo, estudos demonstram que o uso do PRP não promove a neoformação óssea. ${ }^{13,18,21-28}$ Essa divergência de resultados tem sido atribuída a variações intra e inter-espécies na proporção relativa dos componentes do PRP. ${ }^{19,29}$ Dessa forma, a eficácia da aplicação do PRP concomitantemente à colocação de implante de titânio (Ti) para favorecer a osseointegração, assim como sua associação com enxertos ósseos, ainda é objeto de discussão. ${ }^{30-32}$

O objetivo do presente estudo foi determinar os efeitos de coquetel de GFs e proteínas típicos de PRP (referido como GFs+proteínas) em culturas de células humanas e de ratos no desenvolvimento do fenótipo osteogênico sobre superfícies de Ti in vitro. Para evitar as variações inerentes ao PRP, optou-se por avaliar uma única formulação contendo seus principais componentes protéicos. 


\section{MATERIAL E MÉTODOS}

Cultura de células da linhagem osteoblástica derivadas de fragmentos ósseos de processos alveolares humanos

Células da linhagem osteoblástica foram obtidas de fragmentos de osso do processo alveolar (explantes), desprezados durante procedimentos cirúrgicos em doadores saudáveis, sob aprovação do Comitê de Ética em pesquisa com espécimes de tecidos humanos. As células foram isoladas por digestão enzimática utilizando solução de colagenase tipo II (Gibco - Life Technologies, Grand Island, NY), como descrito anteriormente. ${ }^{33}$ As células isoladas e os explantes remanescentes foram misturados e cultivados em meio osteogênico, composto por MEM, modificação alfa (Invitrogen, Carlsbad, CA), suplementado com 10\% de soro fetal bovino (Gibco), $50 \mu \mathrm{g} / \mathrm{mL}$ de gentamicina (Gibco), 0,3 $\mu \mathrm{g} / \mathrm{mL}$ de fungizona (Gibco), $5 \mu \mathrm{g} / \mathrm{mL}$ de ácido ascórbico (Gibco), $7 \mathrm{mM}$ de beta-glicerofosfato (Sigma, St. Louis, MO) e dexametasona a $10^{-7} \mathrm{M}$ (Sigma) em frascos de cultura de $75 \mathrm{~cm}^{2}$ (Corning Incorporated, Costar, Corning, NY). Na subconfluência da cultura primária, foi removido o meio de cultura adicionada solução de tripsina a 0,25\% (Gibco) e ácido etilenodiamino tetra-acético (EDTA) a $1 \mathrm{mM}$ (Gibco) para obtenção de suspensão de células. Em seguida, foram plaqueadas $2 \times 10^{4}$ células/poço $(n=5)$ sobre discos de Ti usinados e polidos (preparados como previamente descrito) ${ }^{34}$ em placas de poliestireno de 24 poços (Corning Incorporated). As subculturas foram mantidas a $37{ }^{\circ} \mathrm{C}$ e atmosfera umidificada contendo $5 \%$ de $\mathrm{CO}_{2}$ e $95 \%$ de ar atmosférico. O meio de cultura foi trocado a cada 3 dias.

\section{Composição do coquetel de fatores de crescimento e proteínas e o protocolo de tratamento}

Os GFs e proteínas do coquetel foram selecionados a partir dos principais componentes de preparações (referidas como extratos ou concentrados) de plaqueta suína ${ }^{14}$ e humana. ${ }^{29,35} \mathrm{O}$ 
coquetel de GFs e proteínas foi diluído em meio osteogênico nas seguintes quantidades: 27 ng/mL PDGF-BB recombinante humano (rh), 22 ng/mL rhTGF- $\beta 1,15$ ng/mL rhTGF- $\beta 2,3,7$ $\mu \mathrm{g} / \mathrm{mL}$ albumina humana derivada do soro, $2 \mu \mathrm{g} / \mathrm{mL}$ fibronectina humana derivada do plasma e $0.5 \mu \mathrm{g} / \mathrm{mL}$ trombospondina derivada das plaquetas (Sigma). As subculturas foram expostas ao coquetel de GFs e proteínas durante os 7 primeiros dias, adicionado nos tempos de 0 e 3 dias, e apenas ao meio osteogênico no período subsequente ( $7^{\underline{0}}$ ao $14^{\underline{0}}$ dia $)$. Esse protocolo de exposição baseou-se no fato de a atividade funcional de plaquetas e os efeitos biológicos dos GFs por elas secretados durarem não mais do que 5 dias em sítios de reparo. ${ }^{11}$ Para os grupos controles não foram acrescidos coquetel de GFs ao meio osteogênico.

\section{Morfologia celular por fluorescência direta e localização de proteínas da matriz extracelular não-colágena por imunofluorescência indireta}

Nos tempos experimentais de 1, 4, 7, 10 e 14 dias, as células foram fixadas por 10 minutos à temperatura ambiente em solução de formaldeído (paraformaldeído a 96\%, Acros Organics, Geel, Bélgica) a 4\% em tampão fosfato a 0,1 M, pH 7,2 (PB). Para a dupla marcação vermelho de Alizarina e sialoproteína óssea (BSP), as células foram fixadas em solução de etanol a $70 \%$ por 60 minutos à temperatura de $4{ }^{\circ} \mathrm{C}$. Após lavagem em $\mathrm{PB}$, as culturas foram submetidas a protocolo para imunomarcação pelo método de imunofluorescência indireta. ${ }^{34}$ As células foram permeabilizadas com solução de Triton X-100 (Acros Organics) a 0,5 \% em PB por 10 minutos, seguida de bloqueio com leite desnatado a 5\% em PB por 30 minutos. Foram incubados anticorpos primários para a detecção de fosfatase alcalina (ALP) humana (monoclonal B4-78, 1:100; Developmental Studies Hybridoma Bank, Iowa City, IA), Ki-67 humano (policlonal, 1:70; Diagnostic Biosystems, Pleasanton, CA), BSP humana (polyclonal LF-100, ${ }^{36}$ 1:1000, gentilmente fornecido por Dr. Larry W. Fisher, NIH, Bethesda, MD), BSP de rato 
(monoclonal WVID1-9C5, 1:200, DSHB) e vinculina humana (monoclonal 1:400, hVIN-1, Sigma), seguidos de incubação com anticorpo secundário anti-camundongo ou anti-coelho conjugado com fluoróforo Alexa Fluor 488 (1:200, Molecular Probes, Invitrogen, Eugene, OR; fluorescência verde) ou 594 (1:200, Molecular Probes; fluorescência vermelha). Faloidina conjugada com Alexa Fluor 488 (1:200, Molecular Probes; fluorescência verde) foi utilizada para visualização das células e de seus limites, pela detecção do citoesqueleto de actina. As incubações dos anticorpos primários e secundários foram realizadas em atmosfera úmida à temperatura ambiente por 60 minutos. A substituição dos anticorpos primários por PB foi usada como controle. Entre cada incubação, as amostras eram lavadas três vezes em PB, 5 minutos cada. Antes da montagem para observação microscópica, os núcleos celulares foram marcados com dihidrocloreto 4',6'-diamidino-2-fenilindole (DAPI, Molecular Probes), 1:300 em água bidestilada, por 5 minutos. Os discos eram montados diretamente em lâminas de vidro e, em seguida, sobre a superfície contendo células, montava-se lamínula de vidro circular de $12 \mathrm{~mm}$ de diâmetro (Fisher Scientific, Suwanee, GA) com meio de montagem anti-fade (Vectashield, Vector Laboratories, Burlingame, CA). As amostras foram examinadas em epiluminação utilizando microscópio de fluorescência Leica modelo DMLB (Leica, Bensheim, Alemanha), com objetivas N Plan, de 10X/0,25 e 20X/0,40, e HCX PL Fluotar, de 40X/0,75, acoplado a uma câmera digital Leica DC 300F, 1.3 megapixel CCD (Leica). As imagens adquiridas foram processadas com o programa Adobe Photoshop.

\section{Morfologia celular por microscopia eletrônica de varredura (MEV)}

Nos tempos experimentais de 1 e 4 dias, as células foram fixadas por 60 minutos à temperatura ambiente em solução de formaldeído (paraformaldeído a 96\%, Acros Organics, Geel, Bélgica) a 4\% em PB. Após lavagem em PB e em água bidestilada, as amostras foram 
examinadas em microscópio eletrônico de varredura (JEOL JSM-6460LV), operado a 7 kV e 50$70 \mathrm{~Pa}$. As imagens adquiridas foram processadas com o programa Adobe Photoshop.

\section{Proliferação e viabilidade celulares}

Nos períodos de 1, 4 e 7 dias, as culturas foram tratadas com solução de tripsina a 0,25 \%, colagenase tipo II a $0,1 \%$ e EDTA a $1 \mathrm{mM}$ (Gibco, Invitrogen) para a liberação das células aderidas ao substrato. O número total de células por poço e a porcentagem de células viáveis e não-viáveis foram determinadas após marcação com azul de Trypan 1\% (Sigma) utilizando um hemocitômetro.

\section{Proporção de células no ciclo celular}

A proporção de células imunomarcadas para Ki-67, nos tempos de 1 e 4 dias, foi determinada por dupla marcação Ki-67/DAPI. O número total de núcleos (DAPI) e de células no ciclo celular (Ki-67 positivas) ${ }^{37}$ nas culturas foi calculado por contagem através de microscópio de fluorescência, com objetiva de $40 X$ ( $n=3$ para cada tratamento e período). Avaliou-se um número não inferior a 200 células nos três discos em cada tempo experimental.

\section{Conteúdo de proteína total}

A dosagem de proteína total foi realizada, aos 4, 7 e 10 dias, seguindo o método de Lowry e cols. ${ }^{38} \mathrm{O}$ meio de cultura dos poços foi removido, os poços lavados três vezes com solução salina tamponada de fosfato (PBS) aquecida a $37^{\circ} \mathrm{C}$ e preenchidos com $2 \mathrm{~mL}$ de água deionizada. As amostras foram submetidas a 5 ciclos de choque térmico, cada um consistindo em 20 minutos a $-20{ }^{\circ} \mathrm{C}$ e 15 minutos a $37{ }^{\circ} \mathrm{C}$. Ao final dos ciclos, $1 \mathrm{~mL}$ do lisado de células de cada 
poço foi transferido para tubos de ensaio, misturado com $1 \mathrm{~mL}$ de solução de Lowry (Sigma) e deixados em repouso à temperatura ambiente por 20 minutos. Após esse período, foi adicionado a cada tubo o volume de $0,5 \mathrm{~mL}$ da solução de reagente de fenol de Folin e Ciocalteau (Sigma) e

novamente deixados em repouso à temperatura ambiente por 30 minutos. Em seguida, a absorbância de cada tubo foi medida em um espectrofotômetro (CE3021, Cecil, Inglaterra) utilizando o comprimento de onda de $680 \mathrm{~nm}$. A concentração de proteína total em cada poço foi calculada a partir de uma curva padrão feita com albumina bovina (Sigma) e expressa em $\mu \mathrm{g} / \mathrm{mL}$.

\section{Atividade de ALP}

A atividade de ALP foi avaliada em alíquota de mesma solução usada na determinação do conteúdo de proteína total, pela liberação de timolftaleína por hidrólise do substrato de timolftaleína monofosfato, utilizando kit comercial de acordo com as instruções do fabricante (Labtest Diagnóstica, Belo Horizonte, MG, Brasil). Inicialmente, $50 \mu \mathrm{L}$ de timolftaleína monofosfato foram misturados com $0,5 \mathrm{~mL}$ de tampão dietanolamina a $0,3 \mathrm{M}, \mathrm{pH} 10,1$, por 2 minutos a $37^{\circ} \mathrm{C}$. À solução foi então acrescentada alíquota de $50 \mu \mathrm{L}$ de lisados obtidos de cada poço, permanecendo por 10 minutos a $37^{\circ} \mathrm{C}$. Para o desenvolvimento de cor, foram adicionados $2 \mathrm{~mL}$ de $\mathrm{Na}_{2} \mathrm{CO}_{3}$ a $0,09 \mathrm{M}$ e $\mathrm{NaOH}$ a 0,25 M. Após 30 minutos, a absorbância foi medida em espectrofotômetro utilizando comprimento de onda de $590 \mathrm{~nm}$ e a ALP, calculada a partir de curva padrão usando a timolftaleína em uma escala de 0,012 a $0,4 \mu$ mol de timolftaleína $/ \mathrm{h} / \mathrm{mL}$. Os dados foram expressos como atividade de ALP normalizada pelo conteúdo de proteína total ( $\mu \mathrm{mol}$ de timolftaleína/h/mg de proteína). 


\section{Detecção histoquímica de formações nodulares de matriz mineralizada}

As culturas, 14 dias pós-plaqueamento, foram lavadas em solução de Hanks (Sigma), fixadas em álcool etílico a $70 \%$ a $4{ }^{\circ} \mathrm{C}$ por 60 minutos e lavadas em PBS e água destilada. Em seguida, foram coradas com vermelho de Alizarina a 2\%, pH 4,2, à T.A. por 15 minutos. Após lavagem em água destilada, as culturas foram processadas para tripla marcação com anticorpo anti-BSP (WVID1-9C5 ou LF-100) e DAPI. As observações foram feitas por epifluorescência.

\section{Experimento de dose-resposta com células de calvária de ratos}

Com o objetivo de avaliar os efeitos de diluições do coquetel de GFs e proteínas no desenvolvimento do fenótipo osteogênico foram utilizadas culturas primárias da calvária de ratos recém-nascidos obtidos por digestão enzimática e cultivados sob as mesmas condições osteogênicas. ${ }^{34,39-41}$ A opção em utilizar tais culturas deve-se ao alto potencial osteogênico destas células, especialmente quando induzidas pela dexametasona. ${ }^{42,43}$ As culturas foram, então, expostas, durante os 7 primeiros dias, a três diferentes diluições do coquetel de GFs e proteínas: 1:1, 1:10 e 1:100 (também referido como GFs+proteínas, GFs+proteínas/10 e GFs+proteínas/100, respectivamente). Baseado em evidências experimentais de que os efeitos do PRP não refletem apenas a combinação dos principais GFs presentes em sua composição, ${ }^{44}$ as células foram também expostas às proteínas presentes no coquetel, sem a presença dos GFs. Os parâmetros avaliados para as culturas da calvária foram: 1) nos dias 7 e 14, imunomarcação para BSP (como descrito acima); 2) no dia 7, viabilidade/proliferação celular pelo método de redução do tetrazólio (MTT); 3) nos dias 7 e 10, conteúdo de proteína total e atividade de ALP e no dia 14, detecção histoquímica de formações nodulares de matriz calcificada (como descritos acima).

O método MTT, para avaliar viabilidade/proliferação celular, está baseado na conversão do sal de tetrazólio amarelo em formazan púrpura após clivagem do anel de tetrazólio por 
enzimas desidrogenases de mitocôndrias intactas, ou seja, a conversão só ocorre em células viáveis. No tempo de 7 dias, as células foram incubadas em meio de cultura contendo $100 \mu \mathrm{L}$ de brometo de 3-[4,5-dimetiltiazol-2-il]-2,5-difeniltetrazólio (MTT, $5 \mathrm{mg} / \mathrm{mL}$ ) em PBS a $37{ }^{\circ} \mathrm{C}$ por 4 horas. $\mathrm{O}$ meio foi removido e acrescentado $1 \mathrm{~mL}$ de isopropanol ácido $(0,04 \mathrm{~N} \mathrm{HCl} \mathrm{em}$ isopropanol). A placa de cultura foi mantida em um agitador de placas por 5 minutos. Alíquotas de $100 \mu \mathrm{L}$ dessa solução de cada poço foram transferidas para placas de 96 poços (Fisher Scientific, Pittsburgh, PA) para posterior quantificação. A densidade óptica foi lida em 570-650 $\mathrm{nm}$ em espectrofotômetro ( $\mu$ Quant, Biotek, Winooski, VT) e os dados foram expressos como absorbância. $^{45}$

As culturas coradas com vermelho de Alizarina foram fotografadas com câmera digital de alta resolução (Canon EOS Digital Rebel, 6.3 megapixels, com lente macro EF100 f/2.8) e em microscópio de fluorescência. A proporção de áreas coradas com vermelho de Alizarina foi determinada a partir de imagens macroscópicas das culturas, usando o programa Image Tool (University of Texas Health Science Center, San Antonio, TX).

\section{Análise estatística}

Os resultados foram apresentados como média e desvio padrão. O teste de Qui-quadrado foi usado para determinar a normalidade dos dados. Os dados numéricos foram, então, comparados utilizando o teste não-paramétrico de Mann-Whitney, para duas amostras independentes, ou o teste não-paramétrico de Kruskal-Wallis, para dados independentes e mais de duas amostras. Quando o resultado do teste era considerado "significante" $(\mathrm{p}<0,05)$, realizava-se em seguida o teste de comparações múltiplas de Fischer, baseado em postos. Os resultados descritos abaixo são representativos de pelo menos duas culturas distintas, tanto para células humanas como de ratos. 


\section{RESULTADOS}

\section{Células derivadas do osso alveolar humano}

A análise morfológica por epifluorescência e MEV (Figuras 1 e 2, respectivamente) demonstrou haver diferenças relevantes entre os grupos avaliados. No $1^{\circ}$ dia, apesar de ambas as culturas apresentarem células com morfologia estrelária, extensões citoplasmáticas mais longas e delgadas estavam presentes em maior proporção nas células expostas a coquetel de GFs e proteínas (Figuras 1A, E; 2A, C). Não houve diferenças importantes nos padrões de marcação para a proteína citoesquelética vinculina, a qual ocorria tipicamente em adesões focais e também difusamente na região perinuclear (Figura 1A, E, detalhes). Nos tempos de 4 e 7 dias pósplaqueamento, as culturas expostas a coquetel de GFs e proteínas exibiam maior densidade celular associada a um maior número de células em divisão mitótica (Figuras 1F, G e 2, compare D com B), sendo que as células, em sua maioria, apresentavam núcleos de dimensões reduzidas (compare na Figura 1, F com B e G com C). No 14ํㅜㄹ dia, áreas de matriz calcificada, coradas com vermelho de Alizarina e marcadas para BSP (Figura 1D, detalhe esquerdo), foram observadas apenas em culturas controles (compare na Figura 1, D com H). Era nítida, nessas culturas, a presença de um maior número de células com aspecto morfológico de apoptose (Figura 1D, detalhe direito). Entretanto, culturas expostas a GFs+proteínas exibiam células com seu longo eixo em uma mesma direção (Figura 1H), ausência de marcação para BSP e reduzida quantidade de células apoptóticas (Figura 1H, detalhes esquerdo e direito, respectivamente).

O número total de células foi estatisticamente maior nas subculturas expostas ao coquetel de GFs e proteínas nos tempos de 4 e 7 dias (Figura 3; Tabela 1), embora apenas no dia 4 tenha se observado aumento significativo no número de células viáveis (Tabela 1). A proliferação celular foi significantemente maior para o grupo GFs+proteínas, quando comparada ao controle (Figuras 4 e 5, Tabela 1). 
Para as culturas expostas ao coquetel de GFs e proteínas, o conteúdo de proteína total apresentou aumento significativo em todos os tempos avaliados (Tabela 1), enquanto que redução relevante de ALP foi observada tanto qualitativa como quantitativamente (Figuras 6 e 7 , Tabela 1). Foi interessante notar que os níveis de atividade de ALP foram reduzidos em mais de 90\% nos dias 7 e 10 (15 e 12 vezes menor, respectivamente). Enquanto que a atividade de ALP em função do tempo revelou maior intensidade em 7 dias para o grupo controle, as culturas expostas ao coquetel de GFs e proteínas exibiram um declínio significativo do dia 4 para os dias 7 e 10, apesar do aumento significativo do conteúdo de proteína total quando comparado ao controle (2, 2,9 e 1,7 vezes maior, respectivamente) 

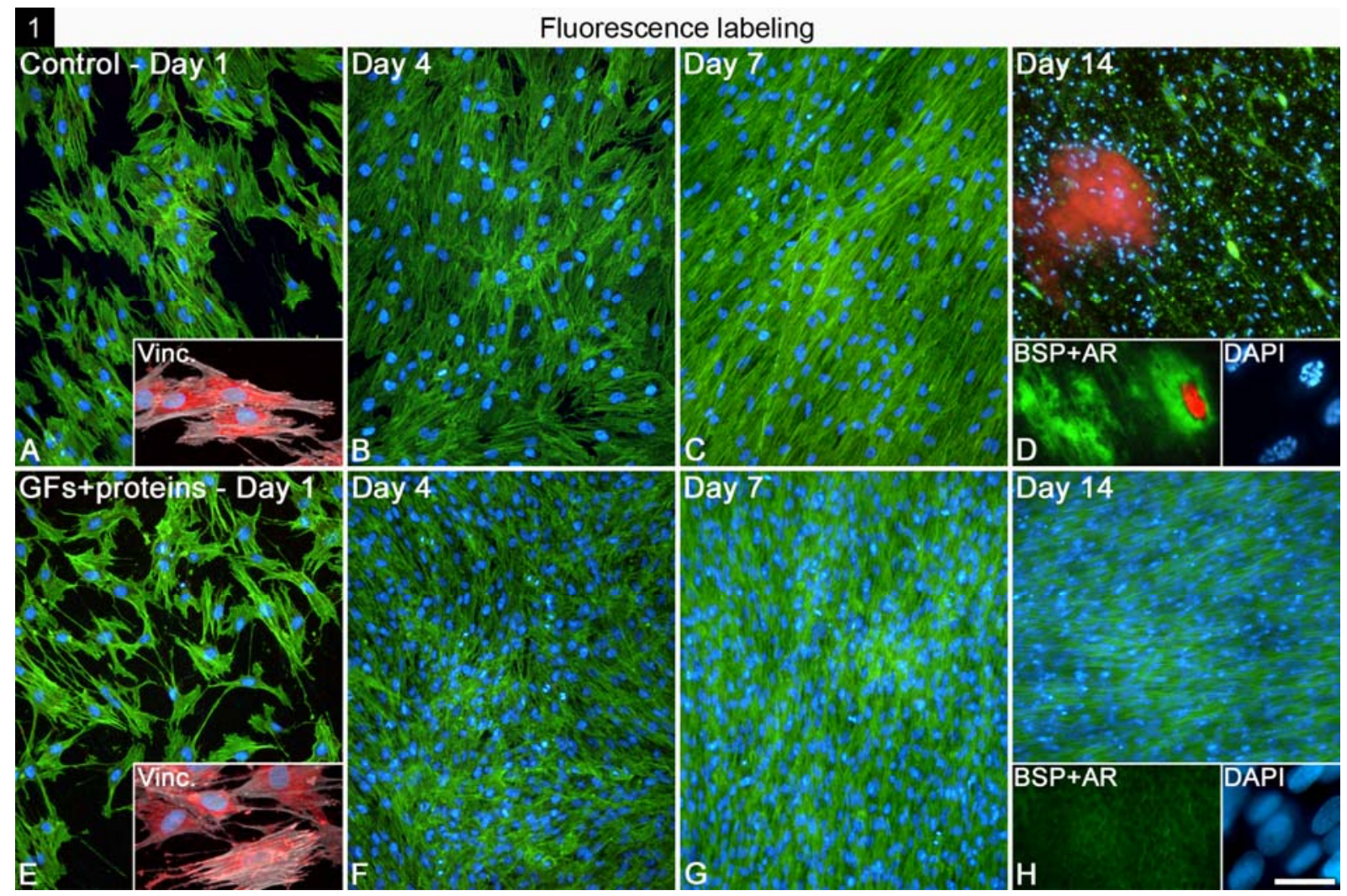

Figura 1. Epifluorescência de culturas de células osteogênicas derivadas de osso alveolar humano crescidas sobre titânio, dos grupos controle (A-D) e GFs+proteínas (E-H), em 1 (A, E), 4 (B, F), 7 (C, G) e 14 (D, H) dias. No $1^{\text {o }}$ dia, ambos os grupos apresentavam células com morfologia estrelária, apesar de o grupo GFs+proteínas exibir células com extensões citoplasmáticas mais longas e delgadas (compare E com A). Não houve diferenças importantes entre os grupos nos padrões de marcação para vinculina, difusa por toda a região perinuclear e em adesões focais (A, E, detalhes; fluorescência vermelha). Nos dias 4, 7 e 14, as culturas expostas ao coquetel de GFs+proteínas exibiam maior número de células se comparado ao controle (compare F-H com B-D). No 14º dia, o grupo controle apresentava áreas focais de matriz calcificada $(\mathrm{D}$, fluorescência vermelha) e núcleos celulares com aspecto morfológico de apoptose ( $\mathrm{D}$, detalhe direito), enquanto que esses aspectos estavam ausentes no grupo GFs+proteínas ( $\mathrm{H}$ e $\mathrm{H}$, detalhe direito). Apenas as culturas controles apresentavam marcação para sialoproteína óssea (BSP) no $14^{\circ}$ dia (fluorescência verde; compare detalhe esquerdo em D com detalhe esquerdo em H), que em algumas áreas eram circunjacentes às formações nodulares marcadas com vermelho de Alizarina (AR, fluorescência vermelha) (D, detalhe esquerdo). Fluorescência verde indica o citoesqueleto de actina para A-H (branca, nos detalhes de $\mathrm{A}$ e E) e a azul, núcleos celulares. Barra para A-H $=100 \mu \mathrm{m} ; \mathrm{A}, \mathrm{E}$ detalhes $=50 \mu \mathrm{m} ; \mathrm{D}, \mathrm{H}$ detalhes esquerdos $=200 \mu \mathrm{m} ; \mathrm{D}, \mathrm{H}$ detalhes direitos $=25 \mu \mathrm{m}$. 


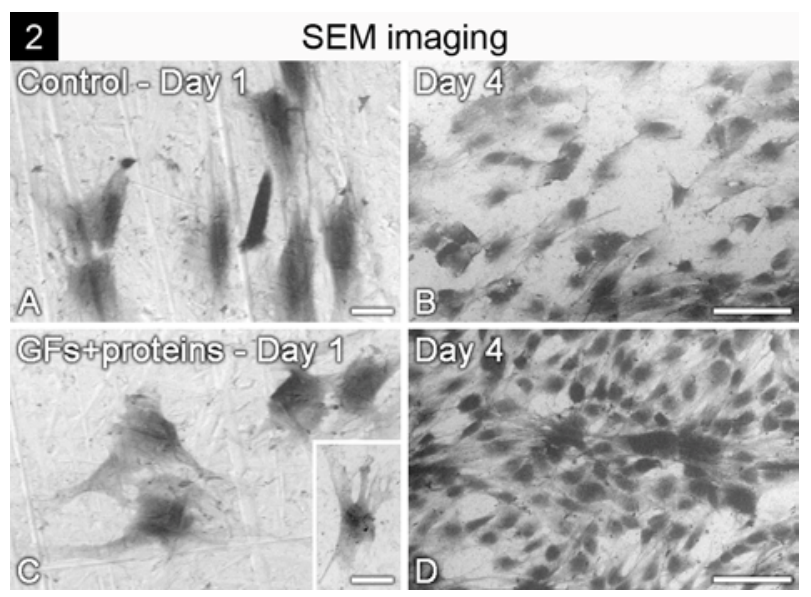

Figura 2. Microscopia eletrônica de varredura de culturas de células osteogênicas derivadas de osso alveolar humano crescidas sobre titânio, dos grupos controle (A, B) e GFs+proteínas (C, D), em 1 (A, C) e 4 (B, D) dias. No $1^{\circ}$ dia, o grupo GFs+proteínas exibia células com extensões citoplasmáticas mais delgadas ( $\mathrm{C}$ e $\mathrm{C}$ detalhe) se comparadas às do controle (A). Em 14 dias, as culturas expostas ao coquetel de GFs e proteínas apresentavam claramente maior número de células (compare D com B). Barra para $\mathrm{A}, \mathrm{C}=20 \mu \mathrm{m} ; \mathrm{C}$, detalhe $=25 \mu \mathrm{m} ; \mathrm{B}, \mathrm{D}=100$ $\mu \mathrm{m}$.

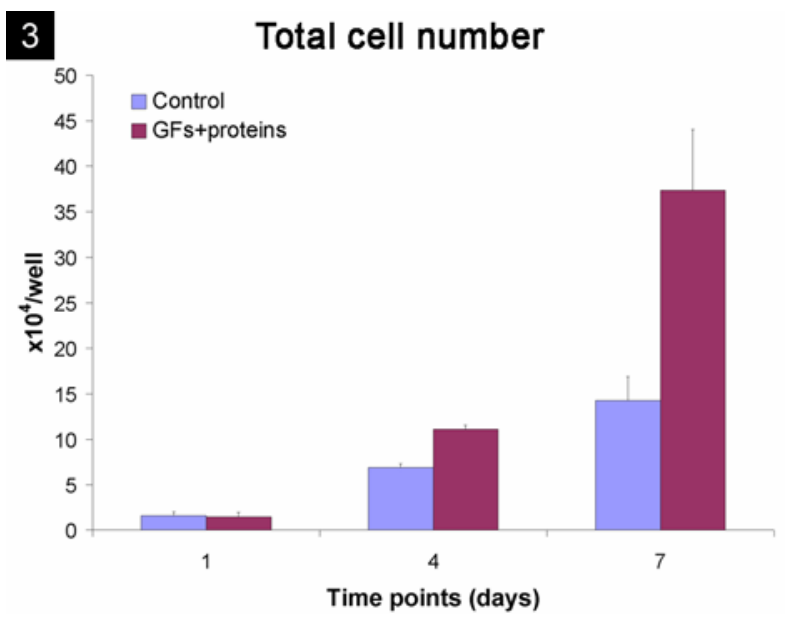

Figura 3. Número total de células de culturas de células osteogênicas derivadas de osso alveolar humano crescidas sobre titânio, dos grupos controle e GFs+proteínas, em 1, 4 e 7 dias. Nos dias 4 e 7, o número total de células foi significativamente maior $(p<0,01)$ para o grupo GFs+proteínas. Os dados são apresentados como média \pm desvio padrão (n=5). 


\section{$4 \quad$ Dual labeling Ki-67 and DAPI}

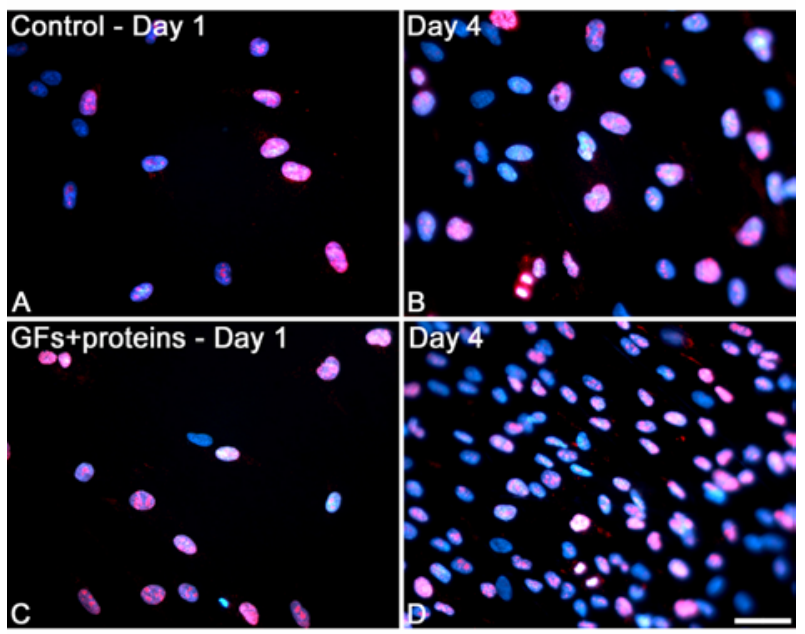

\section{$5 \quad$ Cycling cell number}

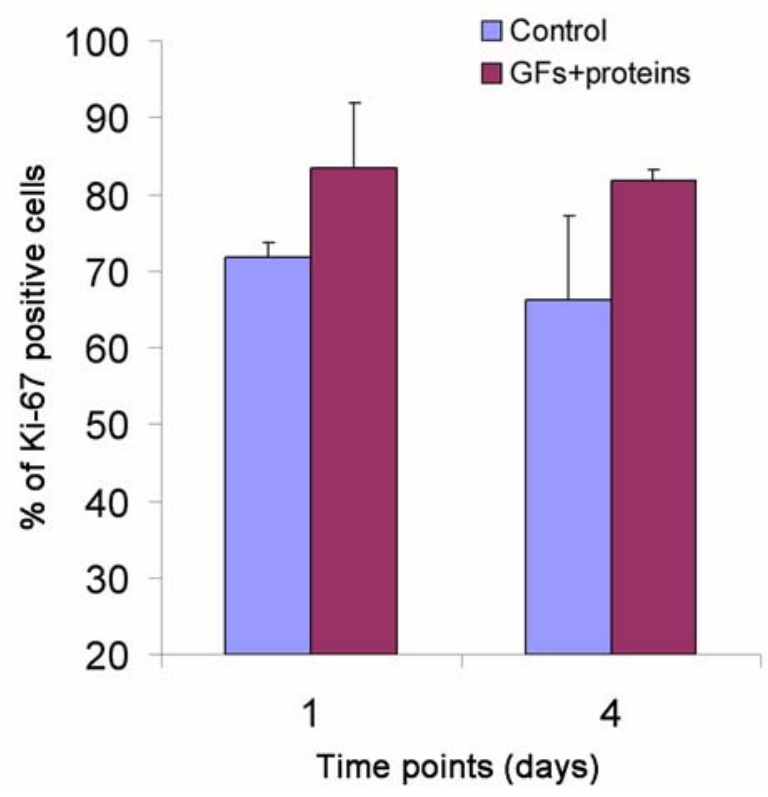

Figura 4. Dupla marcação Ki-67/DAPI (fluorescências vermelha e azul, respectivamente), utilizada para determinar a proporção de células no ciclo celular (Ki-67 positivas) de culturas de células osteogênicas derivadas de osso alveolar humano crescidas sobre titânio, dos grupos controle (A, B) e GFs +proteínas (C, D), em 1 (A, C) e 4 (B, D) dias. Barra para A-D $=50 \mu \mathrm{m}$.

Figura 5. Proporção de células Ki-67 positivas de culturas de células osteogênicas derivadas de osso alveolar humano crescidas sobre titânio, dos grupos controle e GFs+proteínas, em 1 e 4 dias. Aumento significativo ( $p=$ 0,05) foi observado na proporção do número de células no ciclo celular nas culturas exposta ao coquetel de GFs e proteínas. Os dados são apresentados como média \pm desvio padrão (n=3). 

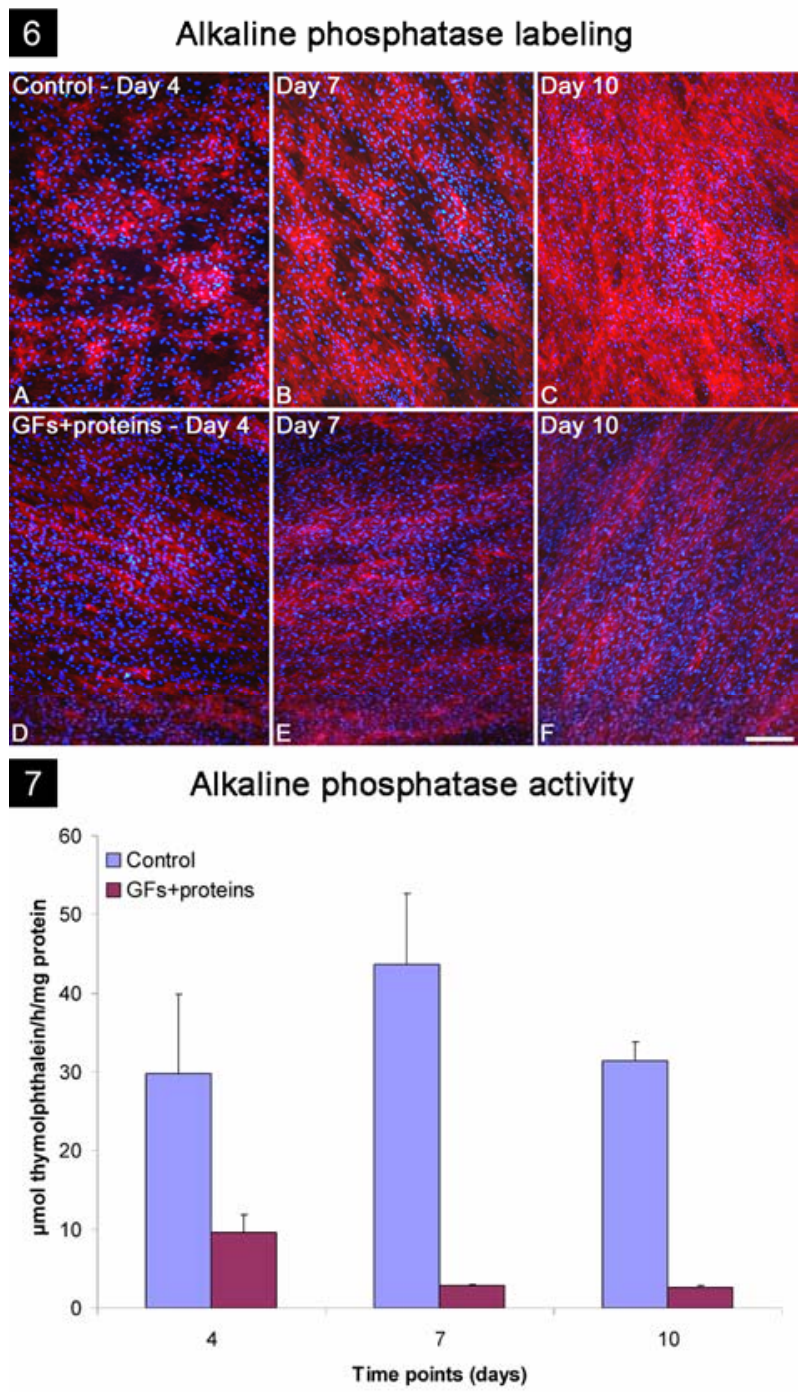

Figura 6. Dupla marcação fosfatase alcalina/DAPI (fluorescências vermelha e azul, respectivamente) de culturas de células osteogênicas derivadas de osso alveolar humano crescidas sobre titânio, dos grupos controle (A-C) e GFs + proteínas (D-F), em 4 (A, D), 7 (B, E), e 10 (C, F) dias. Nas culturas expostas ao coquetel de GFs e proteínas, observa-se marcação para fosfatase alcalina de menor intensidade. Barra para A-F $=200 \mu \mathrm{m}$.

Figura 7. Atividade de fosfatase alcalina ( $\mu \mathrm{mol}$ de timolftaleína/h/mg de proteína) de culturas de células osteogênicas derivadas de osso alveolar humano crescidas sobre titânio, dos grupos controle e GFs+proteínas, em 4, 7 e 10 dias. O grupo GFs+proteínas mostrou redução significativa $(p<0,01)$ nos níveis de atividade dessa enzima. Os dados são apresentados como média \pm desvio padrão ( $\mathrm{n}=5)$. 
TABELA I. Análise quantitativa (média \pm desvio padrão, $n$ ) do número total de células, viabilidade celular, proporção de células no ciclo celular (Ki-67 positivas), conteúdo de proteína total e atividade de fosfatase alcalina (ALP) de culturas de células osteogênicas derivadas de osso alveolar humano crescidas sobre titânio, dos grupos controle e GFs+proteínas

\begin{tabular}{|c|c|c|c|c|}
\hline Parâmetros & $\begin{array}{l}\text { Tempo } \\
\text { (dias) }\end{array}$ & Controle & GFs+proteínas & $\begin{array}{l}\text { Teste de } \\
\text { Mann- } \\
\text { Whitney }\end{array}$ \\
\hline \multirow{3}{*}{$\begin{array}{l}\text { Número total de } \\
\text { células }\left(\times 10^{4}\right)\end{array}$} & 1 & $1,6 \pm 0,4(5)$ & $1,5 \pm 0,5(5)$ & $\mathrm{NS}^{\mathrm{a}}$ \\
\hline & 4 & $6,9 \pm 0,4(5)$ & $11,1 \pm 0,5(5)$ & $\mathrm{S}^{\mathrm{b}}$ \\
\hline & 7 & $14,3 \pm 2,6(5)$ & $37,4 \pm 6,7(5)$ & $\mathrm{S}^{\mathrm{b}}$ \\
\hline \multirow{2}{*}{$\begin{array}{l}\text { Viabilidade celular } \\
(\%)\end{array}$} & 4 & $95,2 \pm 1,6(5)$ & $97 \pm 1,6(5)$ & $\mathrm{S}^{\mathrm{c}}$ \\
\hline & 7 & $95,3 \pm 2(5)$ & $97,3 \pm 0,8(5)$ & $\mathrm{NS}^{\mathrm{a}}$ \\
\hline \multirow{2}{*}{$\begin{array}{l}\text { Células Ki-67 } \\
\text { positivas (\%) }\end{array}$} & 1 & $71,9 \pm 1,7(3)$ & $83,8 \pm 8,6(3)$ & $S^{d}$ \\
\hline & 4 & $66,2 \pm 10,9(3)$ & $81,7 \pm 1,6(3)$ & $\mathrm{S}^{\mathrm{d}}$ \\
\hline \multirow{3}{*}{$\begin{array}{l}\text { Conteúdo de proteína } \\
\text { total }(\mu \mathrm{g} / \mathrm{mL})\end{array}$} & 4 & $16,8 \pm 4,5(5)$ & $33,9 \pm 9,3(5)$ & $S^{b}$ \\
\hline & 7 & $34,6 \pm 5,6(5)$ & $101,5 \pm 15,2(5)$ & $S^{b}$ \\
\hline & 10 & $90 \pm 6,4(5)$ & $150,4 \pm 24,5$ & $\mathrm{~S}^{\mathrm{c}}$ \\
\hline Atividade de ALP & 4 & $29,8 \pm 10,1(5)$ & $9,6 \pm 2,1(5)$ & $S^{b}$ \\
\hline$(\mu \mathrm{mol} \mathrm{de}$ & 7 & $43,6 \pm 9,1(5)$ & $2,8 \pm 0,2(5)$ & $\mathrm{S}^{\mathrm{b}}$ \\
\hline timolftaleína/h/mg) & 10 & $31,4 \pm 2,4(5)$ & $2,6 \pm 0,3(5)$ & $S^{b}$ \\
\hline
\end{tabular}

${ }^{\mathrm{a} N a ̃ o ~ s i g n i f i c a n t e ~}(p>0,05)$.

${ }^{\mathrm{b}}$ Significante $(p<0,01)$.

${ }^{\mathrm{c}}$ Significante $(p<0,05)$.

${ }^{\mathrm{d}}$ Significante $(p=0,05)$. 


\section{Células de calvária de ratos - Experimentos dose-resposta}

Os experimentos dose-resposta demonstraram que apenas o grupo GFs+proteínas/100 desenvolveu o fenótipo osteogênico, apesar dos níveis significativamente reduzidos quando comparados aos dos grupos controle e proteínas (Figuras 8-13). No $7^{\underline{0}}$ dia, as culturas controles exibiam extensas áreas com células imunomarcadas para BSP, principalmente em formações iniciais de multicamadas celulares (Figura 8A), enquanto que os demais grupos apresentavam apenas discreta marcação e em áreas focais (Figura 8B-E). Valores de viabilidade/proliferação celular para os grupos GFs+proteínas/10, GFs+proteínas/100 e proteínas foram semelhantes aos observados para o grupo controle, sendo, no entanto, significativamente maiores para GFs+proteínas (Figura 9; Tabelas 2 e 3). No $7^{\circ}$ dia, os grupos expostos ao coquetel de GFs e proteínas apresentaram redução significativa na atividade de ALP quando comparado ao controle. No $10^{\circ}$ dia, a atividade de ALP aumentou em todos os grupos experimentais, com exceção para o grupo GFs+proteínas, a qual não se alterou, apesar de não haver relação doseresposta. A maior atividade de ALP foi observada para o grupo controle, seguida pelo grupo proteínas (Figura 10; Tabelas 2 e 3). O perfil do gráfico referente aos resultados de conteúdo de proteína total nos dias 7 e 10 assemelhava-se ao obtido para o ensaio de MTT no dia 7 (compare Figura 11 com 9), mostrando valores significativamente maiores para GFs+proteínas (Tabelas 2 e 3). No $14^{\circ}$ dia, análises qualitativa e quantitativa revelaram que os grupos controle, proteínas e GFs+proteínas/100 desenvolveram formações nodulares de matriz mineralizada (Figuras 12 e 13); coradas com vermelho de Alizarina e imunorreativas para BSP (Figura 12A, B, E). As proporções de área total mineralizada para os diferentes grupos seguiram a ordem: controle $=$ proteínas $>$ GFs + proteínas/100 $>$ GFs+proteínas/10 = GFs+proteínas (Figura 13; Tabelas 2 e 3). Observou-se ausência completa de formações nodulares de matriz mineralizada nos grupos GFs+proteínas e GFs+proteínas/10 (Figuras 12C, D e 13). 

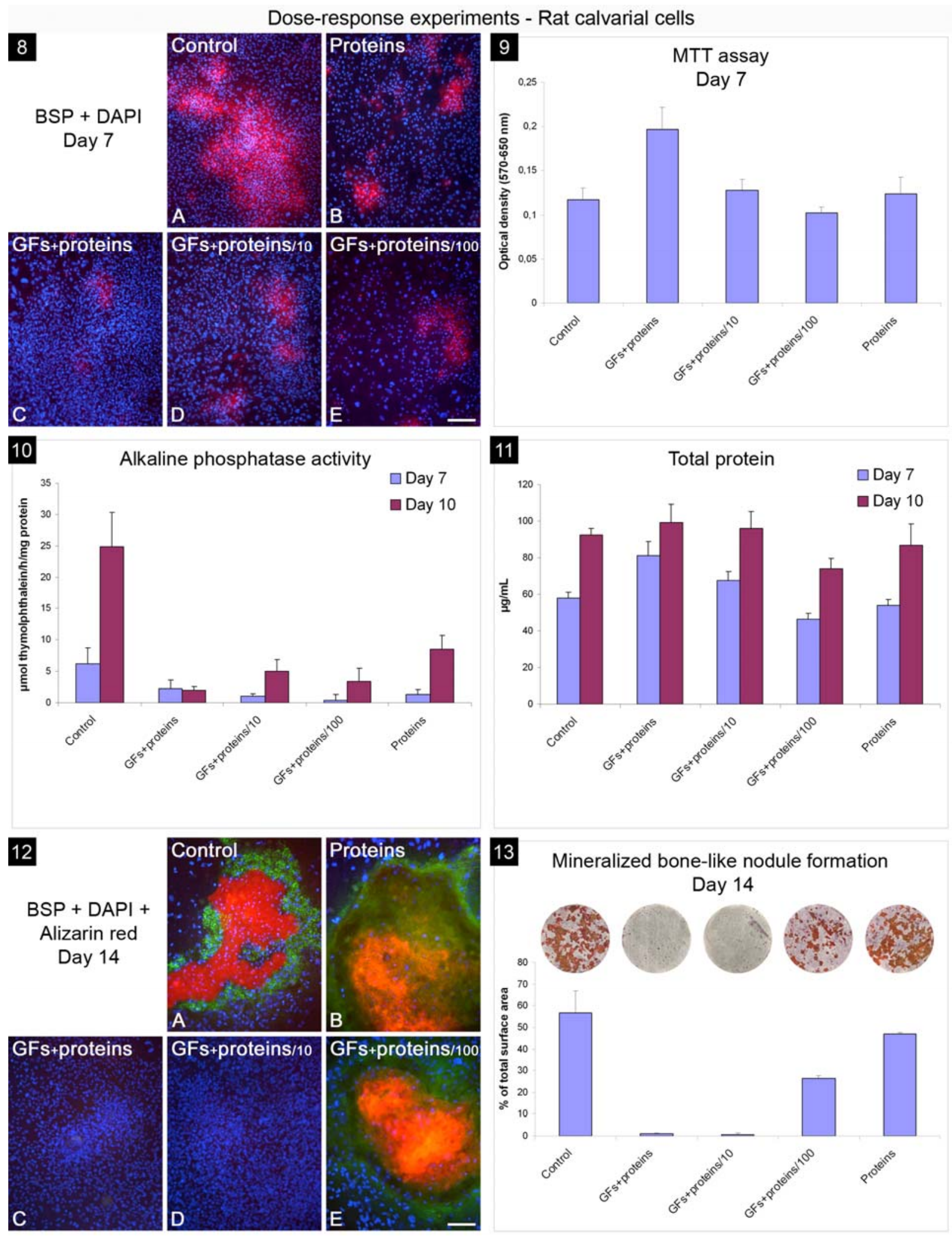
Figura 8. Dupla marcação sialoproteína óssea (BSP, fluorescência vermelha)/DAPI (fluorescência azul) de culturas primárias de células osteogênicas derivadas de calvária de ratos crescidas sobre titânio, dos grupos controle (A), proteínas (B), GFs+proteínas (C), GFs+proteínas/10 (D) e GFs+proteínas/100 (E), em 7 dias. Apenas as culturas controles mostravam áreas mais extensas marcadas para BSP, em sua maioria associadas a formações iniciais de multicamadas celulares (A). Os demais grupos apresentavam marcações para BSP de menor intensidade, em áreas menos extensas (B-E) e apenas focais. Note-se maior densidade de células para o grupo GFs+proteínas (C). Barra para $A-E=200 \mu \mathrm{m}$.

Figura 9. Análise da viabilidade/proliferação celular (Método MTT) de culturas primárias de células osteogênicas derivadas de calvária de ratos crescidas sobre titânio, dos grupos controle, GFs+proteínas, GFs+proteínas/10, GFs+proteínas/100 e proteínas, em 7 dias. O grupo GFs+proteínas apresentou valores de MTT significativamente maiores. A densidade óptica foi lida em 570-650 nm e os dados estão expressos como absorbância.

Figura 10. Atividade de fosfatase alcalina (ALP; $\mu \mathrm{mol}$ de timolftaleína/h/mg) de culturas primárias de células osteogênicas derivadas de calvária de ratos crescidas sobre titânio, dos grupos controle, GFs+proteínas, GFs+proteínas/10, GFs+proteínas/100 e proteínas, em 7 e 10 dias. Não se observa relação dose-resposta para este parâmetro em 10 dias. Os níveis mais baixos de atividade de ALP foram observados para o grupo GFs+proteínas, enquanto que não houve diferença entre as diluições 1:10 e 1:100.

Figura 11. Conteúdo de proteína total $(\mu \mathrm{g} / \mathrm{mL})$ de culturas primárias de células osteogênicas derivadas de calvária de ratos crescidas sobre titânio, dos grupos controle, GFs + proteínas, GFs + proteínas/10, GFs + proteínas/100 e proteínas, em 7 e 10 dias. O gráfico deste parâmetro exibe perfil semelhante ao do ensaio de MTT em 7 dias (compare com Figura 9).

Figura 12. Tripla marcação sialoproteína óssea (BSP, fluorescência verde)/DAPI (fluorescência azul)/vermelho de Alizarina (fluorescência vermelha) de culturas primárias de células osteogênicas derivadas de calvária de ratos crescidas sobre titânio, dos grupos controle (A), proteínas (B), GFs +proteínas (C), GFs +proteínas/10 (D) e GFs+proteínas/100 (E), em 14 dias. Nódulos de matriz calcificada foram apenas observados nos grupos controle, proteínas e GFs+proteínas (A, B, E, corados com vermelho de Alizarina), os quais também apresentavam marcação para BSP (fluorescência verde). Os grupos GFs+proteínas e GFs+proteínas/10 (C e D, respectivamente) não exibiam áreas coradas com vermelho de Alizarina e imunomarcadas para BSP. Barra para A, B, E = $100 \mu \mathrm{m} ; \mathrm{C}, \mathrm{D}=200 \mu \mathrm{m}$.

Figura 13. Imagens macroscópicas e análise quantitativa de áreas coradas com vermelho de Alizarina de culturas primárias de células osteogênicas derivadas de calvária de ratos crescidas sobre titânio, dos grupos controle, GFs+proteínas, GFs+proteínas/10, GFs+proteínas/100 e proteínas, em 14 dias. A proporção da área total corada com vermelho de Alizarina foi significativamente maior para os grupos controle e proteínas. O desenvolvimento de nódulos de matriz calcificada também ocorreu no grupo GFs+proteínas/100, mas em quantidade significativamente menor. Ausência de mineralização das culturas ocorreu nos grupos GFs+proteínas e GFs+proteínas/10. Diâmetro do disco de titânio $=12 \mathrm{~mm}$. 
TABELA II. Análise quantitativa (media \pm desvio padrão, $n$ ) da viabilidade/proliferação celular (método MTT; densidade óptica, 570-650 nm), atividade de fosfatase alcalina (ALP; $\mu$ mol de timolftaleína/h/mg), conteúdo de proteína total $(\mu \mathrm{g} / \mathrm{mL})$, e proporção de áreas coradas com vermelho de Alizarina (AR; \%) de culturas primárias de células osteogênicas derivadas de calvária de ratos crescidas sobre titânio, dos grupos controle, GFs+proteínas, GFs+proteínas/10, GFs+proteínas/100 e proteínas

\begin{tabular}{lcccccc}
\hline \multirow{2}{*}{ Grupos } & $\begin{array}{c}\text { Método } \\
\text { MTT }\end{array}$ & \multicolumn{2}{c}{ Atividade de ALP } & Conteúdo de proteína total & $\begin{array}{c}\text { Áreas } \\
\text { coradas } \\
\text { com AR }\end{array}$ \\
\cline { 2 - 7 } & Dia 7 & Dia 7 & Dia 10 & Dia 7 & Dia 10 & Dia 14 \\
\hline Controle & $0,12 \pm 0,01$ & $6,2 \pm 2,6$ & $24,9 \pm 5,4$ & $58 \pm 3,2$ & $92,6 \pm 3,4$ & $56,6 \pm 10,1$ \\
& $(4)$ & $(5)$ & $(5)$ & $(5)$ & $(5)$ & $(4)$ \\
GFs+proteínas & $0,20 \pm 0,02$ & $2,2 \pm 1,4$ & $2 \pm 0,6$ & $81,3 \pm 7,4$ & $99 \pm 10,1$ & $0,9 \pm 0,3$ \\
& $(4)$ & $(4)$ & $(5)$ & $(4)$ & $(5)$ & $(4)$ \\
GFs+proteínas/10 & $0,13 \pm 0,01$ & $1,0 \pm 0,4$ & $5 \pm 1,9$ & $67,5 \pm 4,9$ & $96 \pm 9,1$ & $0,7 \pm 0,7$ \\
& $(4)$ & $(5)$ & $(5)$ & $(5)$ & $(5)$ & $(4)$ \\
GFs+proteínas/100 & $0,10 \pm 0,01$ & $0,4 \pm 0,9$ & $3,4 \pm 2$ & $46,5 \pm 3,1$ & $73,9 \pm 5,8$ & $26,4 \pm 1,4$ \\
& $(4)$ & $(5)$ & $(5)$ & $(5)$ & $(5)$ & $(4)$ \\
Proteínas & $0,12 \pm 0,02$ & $1,2 \pm 0,9$ & $8,6 \pm 2,1$ & $53,9 \pm 3,5$ & $87 \pm 11,4$ & $46,8 \pm 0,7$ \\
& $(4)$ & $(4)$ & $(4)$ & $(4)$ & $(4)$ & $(4)$ \\
Teste de & & & & & & $\mathrm{S}^{\mathrm{a}}$ \\
Kruskal-Wallis & $\mathrm{S}^{\mathrm{a}}$ & $\mathrm{S}^{\mathrm{a}}$ & $\mathrm{S}^{\mathrm{a}}$ & $\mathrm{S}^{\mathrm{a}}$ & & $\mathrm{S}^{\mathrm{a}}$ \\
\hline
\end{tabular}

${ }^{\mathrm{a} S i g n i f i c a n t e}(p<0,01)$. 
TABELA III. Análise comparativa (Pós-teste de Fischer) da viabilidade/proliferação celular (método MTT), atividade de fosfatase alcalina (ALP), conteúdo de proteína total e proporção de áreas coradas com vermelho de Alizarina (AR) de culturas primárias de células osteogênicas derivadas de calvária de ratos crescidas sobre titânio, dos grupos controle, GFs+proteínas, GFs+proteínas/10, GFs+proteínas/100 e proteínas

\begin{tabular}{|c|c|c|c|c|c|c|}
\hline \multirow[t]{2}{*}{ Comparações (pós-teste de Fischer) } & \multirow{2}{*}{$\begin{array}{c}\begin{array}{c}\text { Método } \\
\text { MTT }\end{array} \\
\text { Dia } 7 \\
\end{array}$} & \multicolumn{2}{|c|}{ Atividade de ALP } & \multicolumn{2}{|c|}{$\begin{array}{l}\text { Conteúdo de } \\
\text { proteína total }\end{array}$} & \multirow{2}{*}{$\begin{array}{c}\begin{array}{c}\text { Áreas } \\
\text { coradas } \\
\text { com AR }\end{array} \\
\text { Dia } 14 \\
\end{array}$} \\
\hline & & Dia 7 & Dia 10 & Dia 7 & Dia 10 & \\
\hline Controle x GFs+proteínas & $1 \%$ & $5 \%$ & $0,1 \%$ & $0,1 \%$ & $\mathrm{NS}^{\mathrm{a}}$ & $0,1 \%$ \\
\hline Controle $\mathrm{x}$ GFs + proteínas $/ 10$ & $\mathrm{NS}^{\mathrm{a}}$ & $0,1 \%$ & $0,1 \%$ & $0,1 \%$ & $\mathrm{NS}^{\mathrm{a}}$ & $0,1 \%$ \\
\hline Controle x GFs+proteínas $/ 100$ & $\mathrm{NS}^{\mathrm{a}}$ & $0,1 \%$ & $0,1 \%$ & $0,1 \%$ & $1 \%$ & $0,1 \%$ \\
\hline Controle x Proteínas & $\mathrm{NS}^{\mathrm{a}}$ & $1 \%$ & $5 \%$ & $5 \%$ & $\mathrm{NS}^{\mathrm{a}}$ & $\mathrm{NS}^{\mathrm{a}}$ \\
\hline GFs + proteínas x GFs + proteínas $/ 10$ & $5 \%$ & $\mathrm{NS}^{\mathrm{a}}$ & $0,1 \%$ & $1 \%$ & $\mathrm{NS}^{\mathrm{a}}$ & $\mathrm{NS}^{\mathrm{a}}$ \\
\hline GFs+proteínas x GFs+proteínas $/ 100$ & $0,1 \%$ & $1 \%$ & $5 \%$ & $0,1 \%$ & $0,1 \%$ & $1 \%$ \\
\hline GFs+proteínas x Proteínas & $1 \%$ & $\mathrm{NS}^{\mathrm{a}}$ & $0,1 \%$ & $0,1 \%$ & $5 \%$ & $0,1 \%$ \\
\hline GFs + proteínas $/ 10$ x GFs + proteínas $/ 100$ & $1 \%$ & $\mathrm{NS}^{\mathrm{a}}$ & $\mathrm{NS}^{\mathrm{a}}$ & $0,1 \%$ & $0,1 \%$ & $0,1 \%$ \\
\hline GFs + proteínas $/ 10 \times$ Proteínas & $\mathrm{NS}^{\mathrm{a}}$ & $\mathrm{NS}^{\mathrm{a}}$ & $5 \%$ & $0,1 \%$ & $\mathrm{NS}^{\mathrm{a}}$ & $0,1 \%$ \\
\hline GFs+proteínas/100 x Proteínas & $5 \%$ & $\mathrm{NS}^{\mathrm{a}}$ & $0,1 \%$ & $1 \%$ & $\mathrm{NS}^{\mathrm{a}}$ & $1 \%$ \\
\hline
\end{tabular}

${ }^{\mathrm{a}}$ Non significant $(p>0.05)$. 


\section{DISCUSSÃO}

A aplicação do PRP para acelerar o reparo ósseo baseia-se no fato de GFs liberados por plaquetas e proteínas plasmáticas intensificarem os eventos celulares que, normalmente, ocorreriam no sítio de reparo. ${ }^{13}$ Os resultados do presente trabalho mostram que o coquetel de GFs e proteínas inibe o desenvolvimento do fenótipo osteogênico de culturas de células osteoblásticas humanas e de ratos crescidas sobre Ti. Apesar da variação entre espécies, a ausência de nódulos de matriz mineralizada foi observada em ambas as culturas analisadas. Além disso, o experimento dose-resposta com células de calvária de ratos demonstrou que a diluição do coquetel pode, eventualmente, restaurar a formação de nódulos de matriz mineralizada. Esses resultados corroboram os estudos in vitro e in vivo que têm mostrado a ineficácia do uso de PRP na promoção de efeitos consistentes nos eventos osteogênicos. ${ }^{13,18,19,21-}$ ${ }^{29} \mathrm{O}$ mesmo ocorre, inclusive, na osseointegração de implantes metálicos. ${ }^{30-32}$

No contexto da biologia óssea, relação inversa entre proliferação e diferenciação celular tem sido amplamente descrita, inclusive para células cultivadas sobre o $\mathrm{Ti}^{46}$ De fato, a fase final de diferenciação osteoblástica está necessariamente associada com a fase G0, fora do ciclo celular. ${ }^{47,48}$ Por essa razão, estratégias de diluir o PRP na tentativa de equilibrar a relação proliferação/diferenciação têm sido utilizadas com o objetivo de melhorar o prognóstico da reparação óssea. ${ }^{18,21,31,49-52}$ É importante ressaltar que o coquetel utilizado apresenta concentração inferior às preparações típicas de PRP e, apesar da diluição 1:10 reduzir significativamente a viabilidade/proliferação ao nível do grupo controle, isso não refletiu em aumento da diferenciação osteoblástica. A diluição 1:100 foi necessária para restaurar a formação de matriz mineralizada. Novos estudos, com o objetivo de alcançar um equilíbrio funcional entre o efeito mitogênico e o processo de diferenciação celular, são necessários para avaliar as diferentes proporções relativas do PRP, alterando os parâmetros de concentração, duração e tempo de exposição. 
A redução dos níveis de atividade de ALP para as culturas expostas ao coquetel de GFs e proteínas é consistente com o efeito sobre a diferenciação osteogênica. Em estudo anterior foi demonstrado que BMP-7 e GDF-5 poderiam, em parte, estimular a diferenciação osteogênica nas culturas expostas ao coquetel de GFs e proteínas através do aumento da expressão de RNAm para ALP. ${ }^{53}$ Contudo, a atividade de ALP e a formação de matriz mineralizada não foram significantemente afetadas, indicando que as células osteoblásticas não atingiam os estágios finais de diferenciação. No presente estudo, os experimentos dose-resposta demonstraram que a atividade de ALP aumentou com a diluição do coquetel e que, apesar de não haver diferença significativa entre as diluições de 1:10 e 1:100, apenas esta desenvolveu o fenótipo osteogênico. Isso sugere que, além da atividade de ALP, outros parâmetros devem ser considerados. De fato, ambos os grupos GFs+proteínas e GFs+proteínas/10 não apresentaram marcação para BSP em 14 dias. Essa proteína matricelular é considerada um marcador inicial da diferenciação osteoblástica, com papel fundamental no processo de nucleação de apatitas na matriz colágena. ${ }^{54,55}$ Contudo, não se pode descartar que a diferença na mineralização entre as diluições 1:10 e 1:100 esteja relacionada à atividade de ALP. Ressalte-se que mesmo uma redução moderada na expressão dessa enzima e em sua atividade pode ser suficiente para limitar o processo de mineralização. ${ }^{56} \mathrm{O}$ procedimento utilizado para avaliar a atividade de ALP não permite detectar pequenas diferenças que possam existir entre estas duas diluições. Além disso, dificuldades na extração de proteínas/enzimas da matriz calcificada poderiam resultar, em alguns casos, em valores de atividade de ALP que não se correlacionam com o conteúdo de proteína total e o número de células. ${ }^{57}$ No tecido ósseo, a ALP está confinada à superfície de osteoblastos, incluindo as membranas das vesículas de matriz que eles secretam, nas quais a ALP é particularmente mais concentrada. Tem sido proposto que o principal papel da ALP é fornecer fosfato necessário para formação de hidroxiapatita. Contudo, tem sido sugerido, também, que a ALP pode hidrolisar o inibidor de mineralização pirofosfato, facilitando a precipitação mineral e 
a formação do tecido ósseo. ${ }^{58}$ Assim, o coquetel de GFs e proteínas poderia também alterar o equilíbrio fosfato/pirofosfato, o qual é considerado crucial para a mineralização da matriz extracelular.

O presente trabalho mostrou que o coquetel de GFs e proteínas, contendo os principais componentes do PRP, limita a progressão de células osteogênicas humanas e de ratos crescidas sobre o Ti. Os experimentos dose-resposta revelaram que a redução da proliferação celular, associada ao aumento dos níveis de ALP, não resulta necessariamente na formação de nódulos de matriz calcificada. Os resultados corroboram estudos prévios indicando que o PRP não promove a reparação óssea em determinadas condições experimentais e clínicas. Além disso, reforçam a necessidade de se questionar o uso de terapias moleculares baseadas em PRP visando a favorecer a osseointegração de implantes. 


\section{REFERÊNCIAS}

1. Bessho K, Carnes DL, Cavin R, Chen HY, Ong JL. BMP stimulation of bone response adjacent to titanium implants in vivo. Clin Oral Implants Res 1999; 10: 212-218.

2. Schliephake H. Bone growth factors in maxillofacial skeletal reconstruction. Int J Oral Maxillofac Surg 2002, 31: 469-484.

3. Ramoshebi LN, Matsaba TN, Teare J, Renton L, Patton J, Ripamonti U. Tissue engineering: TGF-beta superfamily members and delivery systems in bone regeneration. Expert Rev Mol Med 2002; 4: 1-11.

4. Kloen P, Di Paola M, Borens O, Richmond J, Perino G, Helfet DL, Goumans MJ. BMP signaling components are expressed in human fracture callus. Bone 2003; 33: 362-371.

5. Clokie CM, Bell RC. Recombinant human transforming growth factor beta-1 and its effects on osseointegration. J Craniofac Surg 2003; 14: 268-277.

6. De Ranieri A, Virdi AS, Kuroda S, Shott S, Leven RM, Hallab NJ, Sumner DR. Local application of rhTGF-beta 2 enhances peri-implant bone volume and bone-implant contact in a rat model. Bone 2005; 37: 55-62.

7. Jones AA, Buser D, Schenk R, Wozney J, Cochran DL. The effect of rhBMP-2 around endosseous implants with and without membranes in the canine model. J Periodontol 2006; 77: 1184-1193.

8. Hall J, Sorensen RG, Wozney JM, Wikesjö UM. Bone formation at rhBMP-2-coated titanium implants in the rat ectopic model. J Clin Periodontol 2007; 34: 444-451.

9. Liu Y, Enggist L, Kuffer AF, Buser D, Hunziker EB. The influence of BMP-2 and its mode of delivery on the osteoconductivity of implant surfaces during the early phase of osseointegration. Biomaterials 2007; 28: 2677-2686.

10. Bolander ME. Regulation of fracture repair by growth factors. Proc Soc Exp Biol Med 1992; 200: 165-170.

11. Marx RE, Carlson ER, Eichstaedt RM, Schimmele SR, Strauss JE, Georgeff KR. Platelet-rich plasma: Growth factor enhancement for bone grafts. Oral Surg Oral Med Oral Pathol Oral Radiol Endod 1998; 85: 638-646.

12. Dugrillon A, Eichler H, Kern S, Kluter H. Autologous concentrated platelet-rich plasma (cPRP) for local application in bone regeneration. Int J Oral Maxillofac Surg 2002; 31: 615-619.

13. Anitua E, Sánchez M, Orive G, Andia I. The potential impact of the preparation rich in growth factors (PRGF) in different medical fields. Biomaterials 2007; 28: 4551-4560. 
14. Venne D, Raymond J, Allas S, Roy D, Leclerc G, Boushira M, Brazeau P. Healing of experimental aneurysms. II: Platelet extracts can increase the thickness of the neointima at the neck of treated aneurysms. J Neuroradiol 1999; 26: 92-100.

15. Gruber R, Karreth F, Frommlet F, Fischer MB, Watzek G. Platelets are mitogenic for periosteum-derived cells. J Orthop Res 2003; 21: 941-948.

16. Lucarelli E, Beccheroni A, Donati D, Sangiorgi L, Cenacchi A, Del Vento AM, Meotti C, Bertoja AZ, Giardino R, Fornasari PM, Mercuri M, Picci P. Platelet-derived growth factors enhance proliferation of human stromal stem cells. Biomaterials 2003; 24: 30953100 .

17. Borzini P, Mazzucco L. Platelet gels and releasates. Curr Opin Hematol 2005; 12: 473479.

18. Graziani F, Ivanovski S, Cei S, Ducci F, Tonetti M, Gabriele M. The in vitro effect of different PRP concentrations on osteoblasts and fibroblasts. Clin Oral Implants Res 2006; 17: $212-219$.

19. van den Dolder J, Mooren R, Vloon AP, Stoelinga PJ, Jansen JA. Platelet-rich plasma: quantification of growth factor levels and the effect on growth and differentiation of rat bone marrow cells. Tissue Eng 2006; 12: 3067-3073.

20. Borzini P, Mazzucco L. Platelet-rich plasma (PRP) and platelet derivatives for topical therapy. What is true from the biologic view point? ISBT Science Series 2007; 2: 272281.

21. Ferreira CF, Gomes MCC, Filho JS, Granjeiro JM, Simões CMO, Magini RS. Plateletrich plasma influence on human osteoblasts growth. Clin Oral Implants Res 2005; 16: 456-460.

22. Hokugo A, Ozeki M, Kawakami O, Sugimoto K, Mushimoto K, Morita S, Tabata Y. Augmented bone regeneration activity of platelet-rich plasma by biodegradable gelatin hydrogel. Tissue Eng 2005; 11: 1224-1233.

23. Gerard D, Carlson ER, Gotcher JE, Jacobs M. Effects of platelet-rich plasma on the healing of autologous bone grafted mandibular defects in dogs. J Oral Maxillofac Surg 2006; 64: 443-451.

24. Sarkar MR, Augat P, Shefelbine SJ, Schorlemmer S, Huber-Lang M, Claes L, Kinzl L, Ignatius $\mathrm{A}$. Bone formation in a long bone defect model using a platelet-rich plasmaloaded collagen scaffold. Biomaterials 2006; 27: 1817-1823. 
25. Hokugo A, Sawada Y, Hokugo R, Iwamura H, Kobuchi M, Kambara T, Morita S, Tabata Y. Controlled release of platelet growth factors enhances bone regeneration at rabbit calvaria. Oral Surg Oral Med Oral Pathol Oral Radiol Endod 2007; 104: 44-48.

26. Mooren RE, Merkx MA, Bronkhorst EM, Jansen JA, Stoelinga PJ. The effect of plateletrich plasma on early and late bone healing: an experimental study in goats. Int $\mathrm{J}$ Oral Maxillofac Surg 2007; 36: 626-631.

27. Ranly DM, Lohmann CH, Andreacchio D, Boyan BD, Schwartz Z. Platelet-rich plasma inhibits demineralized bone matrix-induced bone formation in nude mice. J Bone Joint Surg Am 2007; 89: 139-147.

28. Roussy Y, Bertrand Duchesne MP, Gagnon G. Activation of human platelet-rich plasmas: effect on growth factors release, cell division and in vivo bone formation. Clin Oral Implants Res 2007; 18: 639-648.

29. Lacoste E, Martineau I, Gagnon G. Platelet concentrates: effects of calcium and thrombin on endothelial cell proliferation and growth factor release. J Periodontol 2003; 74: 14981507.

30. Fuerst G, Gruber R, Tangl S, Sanroman F, Watzek G. Enhanced bone-to-implant contact by platelet-released growth factors in mandibular cortical bone: a histomorphometric study in minipigs. Int J Oral Maxillofac Implants 2003; 18: 685-690.

31. Weibrich G, Hansen T, Kleis W, Buch R, Hitzler WE. Effect of platelet concentration in platelet-rich plasma on peri-implant bone regeneration. Bone 2004; 34: 665-671.

32. Nikolidakis D, van den Dolder J, Wolke JG, Jansen JA. Effect of platelet-rich plasma on the early bone formation around Ca-P-coated and non-coated oral implants in cortical bone. Clin Oral Implants Res 2008; 19: 207-213.

33. Beloti MM, Oliveira PT, Gimenes R, Zaghete MA, Bertolini MJ, Rosa AL. In vitro biocompatibility of a novel membrane of the composite poly(vinylidenetrifluoroethylene)/barium titanate. J Biomed Mater Res A 2006; 79: 282-288.

34. De Oliveira PT, Zalzal SF, Beloti MM, Rosa AL, Nanci A. Enhancement of in vitro osteogenesis on titanium by chemically produced nanotopography. J Biomed Mater Res A 2007; 80: 554-564.

35. Martineau I, Lacoste E, Gagnon G. Effects of calcium and thrombin on growth factor release from platelet concentrates: kinetics and regulation of endothelial cell proliferation. Biomaterials 2004; 25: 4489-4502. 
36. Mintz KP, Grzesik WJ, Midura RJ, Robey PG, Termine JD, Fisher LW. Purification and fragmentation of nondenatured bone sialoprotein: evidence for a cryptic, RGD-resistant cell attachment domain. J Bone Miner Res 1993; 8: 985-995.

37. Scholzen T, Gerdes J. The Ki-67 protein: from the known and the unknown. J Cell Physiol 2000; 182: 311-322.

38. Lowry OH, Rosebrough NJ, Farr AL, Randall RJ. Protein measurement with the Folin phenol reagent. J Biol Chem 1951; 193: 265-275.

39. Nanci A, Zalzal S, Gotoh Y, McKee MD. Ultrastructural characterization and immunolocalization of osteopontin in rat calvarial osteoblast primary cultures. Microsc Res Tech 1996; 33: 214-231.

40. Irie K, Zalzal S, Ozawa H, McKee MD, Nanci A. Morphological and immunocytochemical characterization of primary osteogenic cell cultures derived from fetal rat cranial tissue. Anat Rec 1998; 252: 554-567.

41. De Oliveira PT, Nanci A. Nanotexturing of titanium-based surfaces upregulates expression of bone sialoprotein and osteopontin by cultured osteogenic cells. Biomaterials 2004; 25: 403-413.

42. Bellows CG, Aubin JE. Determination of numbers of osteoprogenitors present in isolated fetal rat calvaria cells in vitro. Dev Biol 1989; 133: 8-13.

43. Bellows CG, Heersche JN, Aubin JE. Determination of the capacity for proliferation and differentiation of osteoprogenitor cells in the presence and absence of dexamethasone. Dev Biol 1990; 140: 132-138.

44. Kawase T, Okuda K, Saito Y, Yoshie H. In vitro evidence that the biological effects of platelet-rich plasma on periodontal ligament cells is not mediated solely by constituent transforming-growth factor-beta or platelet-derived growth factor. J Periodontol 2005; 76: $760-767$.

45. Mosmann T. Rapid colorimetric assay for cellular growth and survival: application to proliferation and cytotoxicity assays. J Immunol Methods 1983; 65: 55-63.

46. van den Dolder J, Spauwen PH, Jansen JA. Evaluation of various seeding techniques for culturing osteogenic cells on titanium fiber mesh. Tissue Eng 2003; 9: 315-325.

47. Stein GS, Lian JB, Stein JL, Van Wijnen AJ, Montecino M. Transcriptional control of osteoblast growth and differentiation. Physiol Rev 1996; 76: 593-629.

48. Thomas DM, Johnson SA, Sims NA, Trivett MK, Slavin JL, Rubin BP, Waring P, McArthur GA, Walkley CR, Holloway AJ, Diyagama D, Grim JE, Clurman BE, Bowtell DD, Lee JS, Gutierrez GM, Piscopo DM, Carty SA, Hinds PW. Terminal osteoblast 
differentiation, mediated by runx 2 and $\mathrm{p} 27 \mathrm{KIP} 1$, is disrupted in osteosarcoma. J Cell Biol 2004; 167: 925-934.

49. Choi BH, Zhu SJ, Kim BY, Huh JY, Lee SH, Jung JH. Effect of platelet-rich plasma (PRP) concentration on the viability and proliferation of alveolar bone cells: an in vitro study. Int J Oral Maxillofac Surg 2005; 34: 420-424.

50. Gruber R, Kandler B, Fischer MB, Watzek G. Osteogenic differentiation induced by bone morphogenetic proteins can be suppressed by platelet-released supernatant in vitro. Clin Oral Implants Res 2006; 17: 188-193.

51. Tomoyasu A, Higashio K, Kanomata K, Goto M, Kodaira K, Serizawa H, Suda T, Nakamura A, Nojima J, Fukuda T, Katagiri T. Platelet-rich plasma stimulates osteoblastic differentiation in the presence of BMPs. Biochem Biophys Res Commun 2007; 361: 62-67.

52. Uggeri J, Belletti S, Guizzardi S, Poli T, Cantarelli S, Scandroglio R, Gatti R. Dosedependent effects of platelet gel releasate on activities of human osteoblasts. J Periodontol 2007; 78: 1985-1991.

53. De Oliveira PT, De Oliva MA, Maximiano WMA, Sebastião KEV, Crippa GE, Ciancaglini P, Beloti MM, Nanci A, Rosa AL. Effects of a mixture of growth factors and proteins on the development of the osteogenic phenotype in human alveolar bone cell cultures. J Histochem Cytochem 2008 Mar 31; Epub ahead of print. http://dx.doi.org/10.1369/jhc.2008.950758.

54. Tye CE, Rattray KR, Warner KJ, Gordon JA, Sodek J, Hunter GK, Goldberg HA. Delineation of the hydroxyapatite-nucleating domains of bone sialoprotein. J Biol Chem 2003; 278: 7949-7955.

55. Tye CE, Hunter GK, Goldberg HA. Identification of the type I collagen-binding domain of bone sialoprotein and characterization of the mechanism of interaction. J Biol Chem 2005; 280: 13487-13492.

56. Wennberg C, Hessle L, Lundberg P, Mauro S, Narisawa S, Lerner UH, Millán JL. Functional characterization of osteoblasts and osteoclasts from alkaline phosphatase knockout mice. J Bone Miner Res 2000; 15: 1879-1888.

57. Simão AM, Beloti MM, Rosa AL, de Oliveira PT, Granjeiro JM, Pizauro JM, Ciancaglini P. Culture of osteogenic cells from human alveolar bone: a useful source of alkaline phosphatase. Cell Biol Int 2007; 31: 1405-1413.

58. Millán JL. Mammalian alkaline phosphatases: from biology to applications in medicine and biotechnology. Weinhein: Wiley VCH; 2006. 337 pp. 
Artigo em Inglês *

*Este artigo foi escrito de acordo com as normas do Journal of Biomedical Materials Research Part A. 
Treatment with a Growth Factor-Protein Mixture Inhibits Formation of Mineralized Nodules in Osteogenic Cell Cultures Grown on Titanium

Marcos Andrade de Oliva ${ }^{1}$, William Marcatti Amarú Maximiano', Larissa Moreira Spínola de Castro ${ }^{1}$, Paulo Eliandro da Silva Junior ${ }^{1}$, Roger Rodrigo Fernandes ${ }^{1}$, Pietro Ciancaglini' ${ }^{2}$, Márcio Mateus Beloti ${ }^{1}$, Antonio Nanci $^{3}$, Adalberto Luiz Rosa ${ }^{1}$, Paulo Tambasco de Oliveira ${ }^{1}$

${ }^{1}$ Cell Culture Laboratory, Faculty of Dentistry of Ribeirão Preto, University of São Paulo, Av. do Café, s/n, CEP 14040-904, Ribeirão Preto, SP, Brazil

${ }^{2}$ Departamento de Química, Faculdade de Filosofia, Ciências e Letras de Ribeirão Preto, Universidade de São Paulo, Ribeirão Preto, SP, Brazil

${ }^{3}$ Laboratory for the Study of Calcified Tissues and Biomaterials, Faculté de Médecine Dentaire, Université de Montréal, P.O. Box 6128, Station Centre-Ville, Montréal, QC H3C 3J7, Canada Correspondence to: Prof. Dr. Paulo Tambasco de Oliveira, Division of Oral Histology, School of Dentistry of Ribeirão Preto, University of São Paulo, Av. do Café, s/n, 14040-904, Ribeirão Preto, SP, Brazil. Tel. + 5516 3602-3978 Fax: + 5516 3633-0999. E-mail address: tambasco@usp.br

Short title: PRP-like mixture inhibits the osteogenic phenotype on Ti 


\section{ABSTRACT}

Background: Despite wide clinical application, the efficacy of platelet-rich plasma (PRP) for repairing bone defects and enhancing osseointegration of metal implants is still subject of debate. The objective of the present study was to evaluate the effects of a well-defined mixture of growth factors (GFs) and proteins (GFs+proteins) on the development of the osteogenic phenotype on titanium (Ti) in vitro. The composition of the mixture was based on the major components found in PRP preparations. Methods: The PRP-like mixture contained PDGF-BB, TGF- $\beta 1$, TGF- $\beta 2$, albumin, fibronectin, and thrombospondin. Osteoblastic cells were obtained by enzymatic digestion of human alveolar bone and cultured under standard osteogenic condition until subconfluence. They were then subcultured on Ti discs up to 14 days. Treated cultures were exposed during the first 7 days to osteogenic medium supplemented with GFs + proteins and to osteogenic medium alone thereafter. Control cultures were exposed to only osteogenic medium throughout the culture interval. Dose-response experiments were carried out using rat primary calvarial cells exposed to GFs+proteins and 1:10 or 1:100 dilutions of the mixture. Results: Treated human-derived cell cultures exhibited a significantly higher number of cells from day 4 on and of cycling cells at days 1 and 4, significantly reduced levels for alkaline phosphatase (ALP) activity, and no Alizarin red stained areas at day 14. Although the 1:10 and 1:100 dilutions restored the proliferative activity of rat calvaria-derived osteogenic cells to control levels, mineralized bone-like nodule formation was only observed with the 1:100 dilution. Conclusions: The present results demonstrated that a PRP-like protein mixture inhibits development of the osteogenic phenotype in both human and rat osteoblastic cell cultures grown on Ti.

Key Words: Titanium, Growth factors, Osteoblasts, Cell culture, Cell differentiation, Cell proliferation, Mineralization. 


\section{INTRODUCTION}

The ability to induce new bone formation around endosseous implants is of critical importance for improving healing, increasing stability, and accelerating functional loading. Various regenerative therapies with growth factors (GFs) have been applied to promote and, in some cases, to induce new bone formation in bone defects, at sites of fracture healing, and around metal implant devices. ${ }^{1-4}$ Recombinant human bone morphogenetic proteins (rhBMPs) and transforming growth factor $\beta$ (rhTGF- $\beta$ ) have been demonstrated in various experimental models to improve key parameters associated with successful osseointegration. ${ }^{1,5-9}$

During bone tissue healing, cells are exposed to various GFs simultaneously, particularly at early response intervals when platelets from the blood clot liberate multiple constituents. ${ }^{10}$ In this context, concentrates of plasma platelets have been exploited for repair of bone defects. ${ }^{11-13}$ These so-called Platelet-Rich Plasma (PRP) preparations are rich in platelet-derived growth factor (PDGF) and TGF- $\beta$, and also contain various plasma proteins. ${ }^{14-20}$ Although beneficial clinical results have been reported, some studies have shown that PRP does not promote bone formation. ${ }^{13,18,21-28}$ These divergent outcomes have been attributed to intra and interspecies variations in the relative proportions of PRP components. ${ }^{19,29}$ Thus, the effectiveness of PRP in enhancing osseointegration of metal implants as well as of bone grafts is still a subject of debate. ${ }^{30-32}$

The objective of our study was to investigate the effects of a mixture of GFs and proteins (hereafter referred to as GFs+proteins) on the development of the osteogenic phenotype on titanium (Ti), using both human and rat cell cultures. To avoid the inherent variations in PRP preparations, we have opted to experiment with a well-defined PRP-like mixture formulated to contain the major components found in PRP extracts. 


\section{MATERIAL AND METHODS}

\section{Culture of osteogenic cells derived from human alveolar bone}

Human alveolar bone fragments were obtained from adult healthy donors, using the research protocols approved by the Committee of Ethics in Research of the School of Dentistry of Ribeirão Preto of the University of São Paulo. Osteogenic cells were isolated by enzymatic digestion of the explants using type II collagenase (Gibco - Life Technologies, Grand Island, NY) as previously described. ${ }^{33}$ They were then cultured in an osteogenic medium consisting of Gibco $\alpha$-Minimum Essential Medium (Invitrogen, Carlsbad, CA) supplemented with 10\% fetal bovine serum (Gibco), $50 \mu \mathrm{g} / \mathrm{mL}$ gentamicin (Gibco), $0.3 \mu \mathrm{g} / \mathrm{mL}$ fungisone (Gibco), $10^{-7} \mathrm{M}$ dexamethasone (Sigma, St. Louis, MO), $5 \mu \mathrm{g} / \mathrm{mL}$ ascorbic acid (Gibco), and $7 \mathrm{mM} \beta$ glycerophosphate (Sigma). Subconfluent cells in primary cultures were harvested after treatment with $1 \mathrm{mM}$ ethylenediamine tetraacetic acid (EDTA) (Gibco) and $0.25 \%$ trypsin (Gibco) and subcultured on polished, machined Ti discs (prepared as described previously). ${ }^{34}$ The discs were placed in 24-well polystyrene plates (Falcon, Franklin Lakes, NJ) and cells were seeded at a density of $2 \times 10^{4}$ cells/well. Cultures were grown at $37^{\circ} \mathrm{C}$ in a humidified atmosphere of $5 \% \mathrm{CO}_{2}$ and $95 \%$ air and the medium was changed every 3 days.

\section{Composition of the GF and protein mixture, and treatment protocol}

The GFs and proteins of the mixture were selected from major components found in porcine $^{14}$ and human ${ }^{29,35}$ platelet preparations (referred to as extracts or concentrates). The GFs and proteins were diluted in osteogenic medium in the following amounts: $27 \mathrm{ng} / \mathrm{mL}$ recombinant human (rh) PDGF-BB, $22 \mathrm{ng} / \mathrm{mL}$ rhTGF- $\beta 1,15 \mathrm{ng} / \mathrm{mL}$ rhTGF- $\beta 2,3.7 \mu \mathrm{g} / \mathrm{mL}$ serum-derived human albumin, $2 \mu \mathrm{g} / \mathrm{mL}$ plasma-derived human fibronectin, and $0.5 \mu \mathrm{g} / \mathrm{mL}$ platelet-derived thrombospondin, all purchased from Sigma. Treated cultures were exposed during the first 7 days to the GFs+proteins mixture, which was added at time 0 and at day 3, and 
to osteogenic medium alone thereafter. The timing of exposure to the GFs+proteins mixture was defined based on the life span of platelets in wounds and the period of the direct influence of its GFs, which is less than 5 days. ${ }^{11}$ Control cultures were exposed to only osteogenic medium throughout the culture period.

\section{Fluorescence labeling}

On days $1,4,7,10$, and 14 , cells were fixed for $10 \mathrm{~min}$ at room temperature (RT) using $4 \%$ paraformaldehyde in $0.1 \mathrm{M}$ sodium phosphate buffer $(\mathrm{PB}), \mathrm{pH} 7.2$. For dual staining with Alizarin red (Sigma) and immunolabeling with bone sialoprotein (BSP), cells were fixed in 70\% ethanol for $60 \mathrm{~min}$ at $4^{\circ} \mathrm{C}$ (see below). After washing in $\mathrm{PB}$, cultures were processed for immunofluorescence labeling as described previously. ${ }^{34}$ Briefly, they were permeabilized with $0.5 \%$ Triton X-100 in PB for 10 min, followed by blocking with 5\% skimmed milk in PB for 30 min. Primary antibodies to human bone alkaline phosphatase (ALP) (monoclonal B4-78, 1:100; Developmental Studies Hybridoma Bank-DSHB, Iowa City, IA), human Ki-67 (polyclonal, 1:70; Diagnostic Biosystems, Pleasanton, CA), human BSP (polyclonal LF-100, ${ }^{36} 1: 1000$, kindly provided by Dr. Larry W. Fisher, NIH, Bethesda, MD), rat BSP (monoclonal WVID1-9C5, 1:200, DSHB), and human vinculin (monoclonal hVIN-1, 1:400, Sigma) were used, followed by Alexa Fluor 488 (green fluorescence) or 594 (red fluorescence)-conjugated goat anti-mouse or anti-rabbit secondary antibody (1:200, Molecular Probes, Invitrogen, Eugene, OR). Alexa Fluor 488 (green fluorescence)-conjugated phalloidin (1:200, Molecular Probes) was used to label actin cytoskeleton. Replacement of the primary antibodies with PB was used as control. All antibody incubations were performed in a humidified environment for $60 \mathrm{~min}$ at RT. Between each incubation step, the samples were washed three times (5 min each) in PB. Before mounting for microscope observation, cell nuclei were stained with $300 \mathrm{nM}$ 4',6-diamidino-2phenylindole, dihydrochloride (DAPI, Molecular Probes) for $5 \mathrm{~min}$ and samples were briefly 
washed with $\mathrm{dH}_{2} \mathrm{O}$. Titanium discs were placed face up on glass slides and mounted with a Fisherbrand 12 mm-round glass coverslip (Fisher Scientific, Suwanee, GA) using an antifade mounting medium (Vectashield, Vector Laboratories, Burlingame, CA). The samples were then examined under epifluorescence using a Leica DMLB light microscope (Leica, Bensheim, Germany), with N Plan $(\times 10 / 0.25, \times 20 / 0.40)$ and HCX PL Fluotar $(\times 40 / 0.75)$ objectives, outfitted with a Leica DC 300F digital camera. The acquired digital images were processed with Adobe Photoshop (Adobe Systems, San Jose, CA).

\section{Scanning electron microscope (SEM) imaging}

At days 1 and 4, cells were fixed for 60 min at RT using 4\% paraformaldehyde in PB, pH 7.2, washed in PB, followed by $\mathrm{dH} 2 \mathrm{O}$. Samples were examined wet in a JEOL JSM-6460LV variable pressure scanning electron microscope operated at $7 \mathrm{kV}$ and 50-70 Pa. Digital images were processed with Adobe Photoshop.

\section{Growth curve and cell viability}

Cells grown for periods of 1,4 , and 7 days were enzymatically detached from Ti discs using $1 \mathrm{mM}$ EDTA, $1.3 \mathrm{mg} / \mathrm{mL}$ collagenase, and $0.25 \%$ trypsin solution (Gibco, Invitrogen). Total number of cells/well, and percentage of viable and nonviable cells were determined after Trypan blue (Sigma) staining using a hemacytometer.

\section{Proportion of cycling cells}

The proportion of cycling cells at days 1 and 4 was determined by means of double Ki67/DAPI labeling. The total number of nuclei (DAPI stained) and of cycling cells (Ki-67 positive $)^{37}$ on control and treated cultures was calculated by light microscope counting under epifluorescence at $\times 40$ objective. A minimum total of 200 cells were counted on three Ti discs at each time point. 


\section{Total protein content}

Total protein content was calculated at days 4, 7, and 10, according to the method described by Lowry et al. ${ }^{38}$ The wells were filled with $2 \mathrm{~mL}$ of deionized water. After 5 cycles of thermal-shock (alternating temperature between $15 \mathrm{~min}$ at $37^{\circ} \mathrm{C}$ and $20 \mathrm{~min}$ at $-20^{\circ} \mathrm{C}$ ) $1 \mathrm{~mL}$ of the sample from each well was mixed with $1 \mathrm{~mL}$ of Lowry solution (Sigma) and left for $20 \mathrm{~min}$ at RT. Subsequently, $0.5 \mathrm{~mL}$ of phenol reagent of Folin and Ciocalteau (Sigma) was added. This was then left for $30 \mathrm{~min}$ at RT, after which absorbance was measured using a spectrophotometer (CE3021; Cecil, Cambridge, UK) at $680 \mathrm{~nm}$. Total protein content was calculated from a standard curve using bovine serum albumin (Sigma), giving a range of 25 to $400 \mu \mathrm{g}$ protein $/ \mathrm{mL}$ and data were expressed as $\mu \mathrm{g}$ protein $/ \mathrm{mL}$.

\section{ALP activity}

ALP activity was assayed in the same lysates used for determining total protein content as the release of thymolphthalein from thymolphthalein monophosphate using a commercial kit (Labtest Diagnóstica, MG, Brazil). Briefly, $50 \mu \mathrm{L}$ of thymolphthalein monophosphate was mixed with $0.5 \mathrm{~mL}$ of $0.3 \mathrm{M}$ diethanolamine buffer, $\mathrm{pH} 10.1$, and left for $2 \mathrm{~min}$ at $37^{\circ} \mathrm{C}$. The solution was then added to $50 \mu \mathrm{L}$ of the lysates obtained from each well for 10 min at $37^{\circ} \mathrm{C}$. For color development, $2 \mathrm{~mL}$ of $0.09 \mathrm{M} \mathrm{Na}_{2} \mathrm{CO}_{3}$ and $0.25 \mathrm{M} \mathrm{NaOH}$ were added. After $30 \mathrm{~min}$, absorbance was measured at $590 \mathrm{~nm}$ and ALP activity was calculated from a standard curve using thymolphthalein to give a range of $0.012-0.4 \mu \mathrm{mol}$ thymolphthalein $/ \mathrm{h} / \mathrm{mL}$. Data were expressed as $\mu \mathrm{mol}$ thymolphthalein per hour per mg protein.

\section{Mineralized bone-like nodule formation}

For the histochemical detection of mineralized bone-like nodule formation, cultures at day 14 were washed in Hanks' balanced salt solution (Sigma) and fixed in 70\% ethanol for 60 
min at $4^{\circ} \mathrm{C}$. The samples were washed in phosphate buffered saline (PBS) and $\mathrm{dH} 2 \mathrm{O}$ and then stained with $2 \%$ Alizarin red, $\mathrm{pH} 4.2$, for $15 \mathrm{~min}$ at RT. After being profusely washed in $\mathrm{dH} 2 \mathrm{O}$, cultures were also processed for triple labeling with anti-BSP antibody (WVID1-9C5 or LF-100) and DAPI, and then observed under epifluorescence.

\section{Dose-response experiments with calvarial cell cultures}

To test the effects of serial dilutions of the GFs+proteins mixture on the development of the osteogenic phenotype, we have used rat osteogenic cells obtained by enzymatic digestion of newborn calvaria and cultured under the same conditions as for human cells. ${ }^{34,39-41}$ This cell model was selected because of its high and-well-defined osteogenic activity, especially in presence of dexamethasone. ${ }^{42,43}$ During the first 7 days of culture, calvarial cells were exposed to three different dilutions of GFs+proteins mixture $(1: 1,1: 10$ and $1: 100$, also referred to as GFs+proteins, GFs+proteins/10, and GFs+proteins/100, respectively). Because many of the PRP effects on cells do not reflect simple combination of its major GFs, ${ }^{44}$ cells were also exposed to the mixture containing only the protein constituents. The parameters evaluated for calvarial cell cultures were: 1) at days 7 and 14, BSP labeling (as described above); 2) at day 7, mitochondrial tetrazolium test (MTT); 3) at days 7 and 10, ALP activity and total protein content, and at day 14, mineralized bone-like nodule formation (as described above).

The MTT assay for cell viability/proliferation is based on the reductive cleavage of yellow tetrazolium salt to a purple formazan compound by the dehydrogenase activity of intact mitochondria. Therefore, this conversion only occurs in living cells. At day 7, cells were incubated with $100 \mu \mathrm{L}$ of 3-[4,5-dimethylthiazol-2-yl]-2,5- diphenyl tetrazolium bromide (5 $\mathrm{mg} / \mathrm{mL}$ ) in PBS at $37^{\circ} \mathrm{C}$ for $4 \mathrm{~h}$. The medium was then aspirated from the well and $1 \mathrm{~mL}$ of acid isopropanol $(0.04 \mathrm{~N} \mathrm{HCl}$ in isopropanol) was added to each well. The plates were then agitated on a plate shaker for $5 \mathrm{~min}$, and $100 \mu \mathrm{L}$ of this solution were transferred to a 96 -well format 
using opaque-walled transparent-bottomed plates (Fisher Scientific, Pittsburgh, PA). The optical density was read at $570-650 \mathrm{~nm}$ on the plate reader ( $\mu$ Quant, Biotek, Winooski, VT) and data were expressed as absorbance. ${ }^{45}$

Alizarin red-stained cultures were photographed with a high-resolution digital camera (Canon EOS Digital Rebel Camera, 6.3 Megapixel CMOS sensor, with a Canon EF $100 \mathrm{~mm}$ f/2.8 macro lens, Canon, Lake Success, NY) and were also imaged by epifluorescence. The percentage of the substrate area occupied by Alizarin red-stained nodules was determined by analyzing the macroscopic images using Image Tool software (University of Texas Health Science Center, San Antonio, TX).

\section{Statistical analysis}

Data are presented as mean \pm standard deviation (SD). The chi-square test was used to determine normality of data sets. Comparisons were then carried out using the non-parametrical Mann-Whitney test, for two independent samples or Kruskal-Wallis test, for multiple comparisons, followed by the Fischer test based on rank, where appropriate. The level of significance was set at 5\%. The results described below are representative of a minimum of 2 sets of human and rat osteogenic cell cultures. 


\section{RESULTS}

\section{Human alveolar bone-derived cells}

Important differences were clearly noticed in terms of cell morphology and tissue architecture from day 1 on between control and GFs+proteins treated cultures as revealed by epifluorescence and SEM imaging (Figures 1 and 2, respectively). At day 1, although both control and treated cells were polygonal in shape, the latter exhibited higher proportion of thin cytoplasmic extensions (Figures 1A,E and 2A,C). For both groups, vinculin labeling was localized perinuclearly and in focal adhesions sites (Figure 1A,E, insets). At days 4 and 7, treated cultures exhibited a higher cell density and abundant mitoses (Figures 1F,G and 2, compare D with B), with the majority of cells showing smaller nuclear dimensions compared to control cells (compare in Figure 1, F with B and G with C). Noticeably, areas of calcified matrix were only detected in control cultures at day 14 (compare in Figure 1, D with H), and these exhibited a higher proportion of cells showing morphologic aspects of apoptosis (Figure 1D, right inset). Calcified nodular areas stained with Alizarin red and labeled for BSP (Figure 1D, left inset). At this culture interval, treated cultures showed cell alignment (Figure 1H), no BSP labeling and reduced amounts of apoptotic cells (Figure 1H, left and right insets, respectively).

Cell proliferation/viability analyses revealed that treated cultures supported the growth of significantly more cells at days 4 and 7 (Figure 3, Table 1) and higher number of viable cells at day 4 (Table 1). The proportion of cycling cells was significantly higher for treated cultures both at days 1 and 4 (Figures 4 and 5, Table 1) compared to the control.

Total protein content was significantly higher in treated cultures at all time points and the amount of ALP, as determined by activity measurements and immunolabeling of the protein, was reduced (Figures 6 and 7, Table 1). Notably, at days 7 and 10 ALP specific activity levels were reduced more than $90 \%$ compared to control (15- and 12-fold, respectively). While the profile of ALP activity over time revealed peak levels at day 7 for control cultures, the GFs+proteins group 
exhibited a significant decrease from day 4 to days 7 and 10, despite the significant increase in the total of protein content compared to control (2, 2.9, and 1.7-fold, respectively).

\section{Rat calvarial cells - Dose-response experiments}

Dose-response experiments showed that only GFs+proteins/100 group supported the development of the osteogenic phenotype, although in reduced levels compared to control and proteins groups (Figures 8-13). At day 7, control cultures exhibited large areas of BSP positive cells, mostly in sites of initial cell multilayering (Figure 8A), whereas treated cultures showed only focal sites of weak BSP labeling (Figure 8B-E). Cell viability/proliferation assay revealed that mitochondrial activity was significantly higher for GFs+proteins cultures, reducing to control levels for GFs+proteins/10 and GFs+proteins/100 groups (Figure 9, Tables 2 and 3). At day 7, there was a significant difference in ALP activity between the control and the GFs+proteins treated groups, which exhibited low levels. At day 10, ALP specific activity increased in all experimental groups, except for GFs+proteins, which remained unaltered, but there was no significant GFs+proteins dose-response relationship. The highest ALP activity was observed with the control, followed by the proteins only group (Figure 10, Tables 2 and 3). Total protein content profiles at days 7 and 10 correlated with the MTT results at day 7 (compare Figure 11 with Figure 9), with significantly higher values for GFs+proteins cultures (Tables 2 and 3). At day 14, qualitative and quantitative analyses revealed that control, proteins and GFs+proteins/100 groups supported the development of mineralized bone-like nodule formation (Figures 12 and 13); nodules stained with Alizarin red and were BSP immunoreactive (Figure 12A,B,E). Proportions of Alizarin red stained areas ranked as follows: Control $=$ Proteins $>$ $\mathrm{GFs}+$ proteins $/ 100>\mathrm{GFs}+$ proteins $/ 10=\mathrm{GFs}+$ proteins (Figure 13, Tables 2 and 3). Strikingly, a complete lack of bone-like nodule formation was noticed for GFs+proteins and GFs + proteins/10 treated cultures (Figures 12C,D and 13). 


\section{DISCUSSION}

The use of PRP to enhance tissue repair relies on the concentrated release of platelet GFs for enhancing cellular events that normally take place at wound healing sites. ${ }^{13}$ The results of the present study show that a mixture of major GFs and proteins found in platelet extracts dramatically inhibits development of the osteogenic phenotype in both human alveolar bone and rat calvarial cell cultures grown on Ti. Remarkably, despite interspecies variations, complete lack of bone-like nodule formation took place in both cultures. In addition, dose-response experiments with calvarial cells revealed that dilution of the mixture can eventually partially restore bone-like nodule formation. These data are in accordance with various in vitro and in vivo studies showing that PRP has no consistent effects on osteogenic events, ${ }^{13,18,19,21-29}$ including osseointegration of metal implants. ${ }^{30-32}$

It has been well-established that there is an inverse relationship between proliferation and differentiation of osteoblastic cells, including for cells cultured on $\mathrm{Ti}^{46}{ }^{4 n d e e d}$, full expression of the osteoblast phenotype leads to terminal cell cycle exit. ${ }^{47,48}$ To make bone repair more predictable, there have been attempts to balance proliferation/differentiation by using serial dilutions of PRP preparations. ${ }^{18,21,31,49-52}$ Our GFs+proteins mixture is less concentrated than typical PRP preparations and, although a 1:10 dilution significantly reduced cell proliferation, it did not enhance osteoblastic differentiation. A dilution of 1:100 was necessary to restore bonelike nodule formation. Clearly, further studies are needed to optimize the relative proportions of PRP components, and duration and timing of exposure to achieve a functional balance between mitogenic activity and osteoblast differentiation effects of PRP-related GF and protein mixtures.

The inhibition of ALP activity in both human and rat osteogenic cultures treated with GFs+proteins is consistent with an effect on osteogenic differentiation. In a previous study by our group, it was shown that BMP-7 and GDF-5 could, in part, influence osteogenic differentiation in GFs + proteins treated cultures by upregulating ALP mRNA expression. ${ }^{53}$ ALP 
activity and mineralized nodule formation were, however, not significantly affected, a finding interpreted as reflecting an early differentiation status of the cells. In the present study, the doseresponse experiments showed that ALP activity increases with dilution of the mixture, and while there is no significant difference in activity between the 1:10 or 1:100 dilutions, only the latter supported mineral deposition. This suggests that, in addition to ALP activity, other parameters must be taken in consideration for initiating and sustaining the mineralization process. Indeed, both GFs+proteins and GFs+proteins/10 showed no BSP labeling at day 14. This matricellular protein is considered an early marker of differentiating osteoblasts and is crucial for promoting hydroxyapatite nucleation on collagen. ${ }^{54,55}$ However, it cannot be ruled out that the difference in mineralization observed between the 1:10 and 1:100 dilutions relates to ALP activity. It has been demonstrated that even a moderate reduction in ALP expression levels and enzyme activity could be sufficient to impair the mineralization process. ${ }^{56}$ The procedure used herein to assay ALP activity does not allow determining small differences that may exist between the two dosages. In addition, difficulties in extraction of proteins/enzymes from calcified matrices could in some cases result in ALP specific activity values that do not accurately correlate with total protein content and cell number. ${ }^{57}$ In bone, ALP is confined to the cell surface of osteoblasts, including the membranes of the matrix vesicle they shed, where the enzyme is particularly enriched compared with the plasma membrane of the cell. It has been proposed that the main role of ALP is to generate the phosphate needed for hydroxyapatite formation. However, ALP has also been hypothesized to hydrolyze pyrophosphate, a mineralization inhibitor, in order to facilitate mineral precipitation and growth. ${ }^{58}$ Therefore, treatment with GFs+proteins may also affect the phosphate/pyrophosphate equilibrium, which per se is crucial for the regulation of matrix mineralization.

In conclusion, the present study demonstrates that a GFs+proteins mixture, which contains the major components of PRP preparations, impairs the progression of both human and 
rat osteogenic cells grown on Ti. Dose-response experiments showed that the reduction in cell proliferation associated with higher ALP activity levels does not necessarily correlate with production of mineralized matrix. Thus, our data lend support to previous studies showing that PRP preparations do not promote bone repair under various experimental and clinical conditions. They also raise the question of whether PRP-based multiple component molecular therapy can benefit osseointegration of implants.

\section{Funded by:}

State of São Paulo Research Foundation (FAPESP, Brazil)

National Council of Scientific and Technological Development (CNPq, Brazil)

Canadian Institutes of Health Research (CIHR)

Natural Sciences and Engineering Research Council of Canada (NSERC)

\section{Acknowledgements}

The authors thank Sylvia Francis Zalzal (Université de Montréal, Montréal, QC, Canada) for SEM analysis and imaging, and Dr. Larry W. Fisher (NIH, Bethesda, MD) for providing the anti-human BSP (LF-100) antibody. Marcos Andrade de Oliva and Larissa Moreira Spínola de Castro are recipients of Masters Scholarships from FAPESP. William Marcatti Amarú Maximiano and Paulo Eliandro da Silva Junior were recipients of Internships Scholarships from FAPESP and CNPq, respectively. The mouse monoclonal antibodies anti-human bone ALP (B478), developed by Jerry A. Katzmann, and anti-rat BSP (WVID1-9C5), developed by Michael Solursh and Ahnders Franzen, were obtained from the Developmental Studies Hybridoma Bank developed under the auspices of the NICHD and maintained by the Department of Biological Sciences of the University of Iowa (Iowa City, IA 52242). 


\section{REFERENCES}

1. Bessho K, Carnes DL, Cavin R, Chen HY, Ong JL. BMP stimulation of bone response adjacent to titanium implants in vivo. Clin Oral Implants Res 1999; 10: 212-218.

2. Schliephake H. Bone growth factors in maxillofacial skeletal reconstruction. Int J Oral Maxillofac Surg 2002, 31: 469-484.

3. Ramoshebi LN, Matsaba TN, Teare J, Renton L, Patton J, Ripamonti U. Tissue engineering: TGF-beta superfamily members and delivery systems in bone regeneration. Expert Rev Mol Med 2002; 4: 1-11.

4. Kloen P, Di Paola M, Borens O, Richmond J, Perino G, Helfet DL, Goumans MJ. BMP signaling components are expressed in human fracture callus. Bone 2003; 33: 362-371.

5. Clokie CM, Bell RC. Recombinant human transforming growth factor beta-1 and its effects on osseointegration. J Craniofac Surg 2003; 14: 268-277.

6. De Ranieri A, Virdi AS, Kuroda S, Shott S, Leven RM, Hallab NJ, Sumner DR. Local application of rhTGF-beta 2 enhances peri-implant bone volume and bone-implant contact in a rat model. Bone 2005; 37: 55-62.

7. Jones AA, Buser D, Schenk R, Wozney J, Cochran DL. The effect of rhBMP-2 around endosseous implants with and without membranes in the canine model. J Periodontol 2006; 77: 1184-1193.

8. Hall J, Sorensen RG, Wozney JM, Wikesjö UM. Bone formation at rhBMP-2-coated titanium implants in the rat ectopic model. J Clin Periodontol 2007; 34: 444-451.

9. Liu Y, Enggist L, Kuffer AF, Buser D, Hunziker EB. The influence of BMP-2 and its mode of delivery on the osteoconductivity of implant surfaces during the early phase of osseointegration. Biomaterials 2007; 28: 2677-2686.

10. Bolander ME. Regulation of fracture repair by growth factors. Proc Soc Exp Biol Med 1992; 200: 165-170.

11. Marx RE, Carlson ER, Eichstaedt RM, Schimmele SR, Strauss JE, Georgeff KR. Platelet-rich plasma: Growth factor enhancement for bone grafts. Oral Surg Oral Med Oral Pathol Oral Radiol Endod 1998; 85: 638-646.

12. Dugrillon A, Eichler H, Kern S, Kluter H. Autologous concentrated platelet-rich plasma (cPRP) for local application in bone regeneration. Int J Oral Maxillofac Surg 2002; 31: 615-619.

13. Anitua E, Sánchez M, Orive G, Andia I. The potential impact of the preparation rich in growth factors (PRGF) in different medical fields. Biomaterials 2007; 28: 4551-4560. 
14. Venne D, Raymond J, Allas S, Roy D, Leclerc G, Boushira M, Brazeau P. Healing of experimental aneurysms. II: Platelet extracts can increase the thickness of the neointima at the neck of treated aneurysms. J Neuroradiol 1999; 26: 92-100.

15. Gruber R, Karreth F, Frommlet F, Fischer MB, Watzek G. Platelets are mitogenic for periosteum-derived cells. J Orthop Res 2003; 21: 941-948.

16. Lucarelli E, Beccheroni A, Donati D, Sangiorgi L, Cenacchi A, Del Vento AM, Meotti C, Bertoja AZ, Giardino R, Fornasari PM, Mercuri M, Picci P. Platelet-derived growth factors enhance proliferation of human stromal stem cells. Biomaterials 2003; 24: 30953100 .

17. Borzini P, Mazzucco L. Platelet gels and releasates. Curr Opin Hematol 2005; 12: 473479.

18. Graziani F, Ivanovski S, Cei S, Ducci F, Tonetti M, Gabriele M. The in vitro effect of different PRP concentrations on osteoblasts and fibroblasts. Clin Oral Implants Res 2006; 17: 212-219.

19. van den Dolder J, Mooren R, Vloon AP, Stoelinga PJ, Jansen JA. Platelet-rich plasma: quantification of growth factor levels and the effect on growth and differentiation of rat bone marrow cells. Tissue Eng 2006; 12: 3067-3073.

20. Borzini P, Mazzucco L. Platelet-rich plasma (PRP) and platelet derivatives for topical therapy. What is true from the biologic view point? ISBT Science Series 2007; 2: 272281.

21. Ferreira CF, Gomes MCC, Filho JS, Granjeiro JM, Simões CMO, Magini RS. Plateletrich plasma influence on human osteoblasts growth. Clin Oral Implants Res 2005; 16: 456-460.

22. Hokugo A, Ozeki M, Kawakami O, Sugimoto K, Mushimoto K, Morita S, Tabata Y. Augmented bone regeneration activity of platelet-rich plasma by biodegradable gelatin hydrogel. Tissue Eng 2005; 11: 1224-1233.

23. Gerard D, Carlson ER, Gotcher JE, Jacobs M. Effects of platelet-rich plasma on the healing of autologous bone grafted mandibular defects in dogs. J Oral Maxillofac Surg 2006; 64: 443-451.

24. Sarkar MR, Augat P, Shefelbine SJ, Schorlemmer S, Huber-Lang M, Claes L, Kinzl L, Ignatius $\mathrm{A}$. Bone formation in a long bone defect model using a platelet-rich plasmaloaded collagen scaffold. Biomaterials 2006; 27: 1817-1823. 
25. Hokugo A, Sawada Y, Hokugo R, Iwamura H, Kobuchi M, Kambara T, Morita S, Tabata Y. Controlled release of platelet growth factors enhances bone regeneration at rabbit calvaria. Oral Surg Oral Med Oral Pathol Oral Radiol Endod 2007; 104: 44-48.

26. Mooren RE, Merkx MA, Bronkhorst EM, Jansen JA, Stoelinga PJ. The effect of plateletrich plasma on early and late bone healing: an experimental study in goats. Int $\mathrm{J}$ Oral Maxillofac Surg 2007; 36: 626-631.

27. Ranly DM, Lohmann CH, Andreacchio D, Boyan BD, Schwartz Z. Platelet-rich plasma inhibits demineralized bone matrix-induced bone formation in nude mice. J Bone Joint Surg Am 2007; 89: 139-147.

28. Roussy Y, Bertrand Duchesne MP, Gagnon G. Activation of human platelet-rich plasmas: effect on growth factors release, cell division and in vivo bone formation. Clin Oral Implants Res 2007; 18: 639-648.

29. Lacoste E, Martineau I, Gagnon G. Platelet concentrates: effects of calcium and thrombin on endothelial cell proliferation and growth factor release. J Periodontol 2003; 74: 14981507.

30. Fuerst G, Gruber R, Tangl S, Sanroman F, Watzek G. Enhanced bone-to-implant contact by platelet-released growth factors in mandibular cortical bone: a histomorphometric study in minipigs. Int J Oral Maxillofac Implants 2003; 18: 685-690.

31. Weibrich G, Hansen T, Kleis W, Buch R, Hitzler WE. Effect of platelet concentration in platelet-rich plasma on peri-implant bone regeneration. Bone 2004; 34: 665-671.

32. Nikolidakis D, van den Dolder J, Wolke JG, Jansen JA. Effect of platelet-rich plasma on the early bone formation around Ca-P-coated and non-coated oral implants in cortical bone. Clin Oral Implants Res 2008; 19: 207-213.

33. Beloti MM, Oliveira PT, Gimenes R, Zaghete MA, Bertolini MJ, Rosa AL. In vitro biocompatibility of a novel membrane of the composite poly(vinylidenetrifluoroethylene)/barium titanate. J Biomed Mater Res A 2006; 79: 282-288.

34. De Oliveira PT, Zalzal SF, Beloti MM, Rosa AL, Nanci A. Enhancement of in vitro osteogenesis on titanium by chemically produced nanotopography. J Biomed Mater Res A 2007; 80: 554-564.

35. Martineau I, Lacoste E, Gagnon G. Effects of calcium and thrombin on growth factor release from platelet concentrates: kinetics and regulation of endothelial cell proliferation. Biomaterials 2004; 25: 4489-4502. 
36. Mintz KP, Grzesik WJ, Midura RJ, Robey PG, Termine JD, Fisher LW. Purification and fragmentation of nondenatured bone sialoprotein: evidence for a cryptic, RGD-resistant cell attachment domain. J Bone Miner Res 1993; 8: 985-995.

37. Scholzen T, Gerdes J. The Ki-67 protein: from the known and the unknown. J Cell Physiol 2000; 182: 311-322.

38. Lowry OH, Rosebrough NJ, Farr AL, Randall RJ. Protein measurement with the Folin phenol reagent. J Biol Chem 1951; 193: 265-275.

39. Nanci A, Zalzal S, Gotoh Y, McKee MD. Ultrastructural characterization and immunolocalization of osteopontin in rat calvarial osteoblast primary cultures. Microsc Res Tech 1996; 33: 214-231.

40. Irie K, Zalzal S, Ozawa H, McKee MD, Nanci A. Morphological and immunocytochemical characterization of primary osteogenic cell cultures derived from fetal rat cranial tissue. Anat Rec 1998; 252: 554-567.

41. De Oliveira PT, Nanci A. Nanotexturing of titanium-based surfaces upregulates expression of bone sialoprotein and osteopontin by cultured osteogenic cells. Biomaterials 2004; 25: 403-413.

42. Bellows CG, Aubin JE. Determination of numbers of osteoprogenitors present in isolated fetal rat calvaria cells in vitro. Dev Biol 1989; 133: 8-13.

43. Bellows CG, Heersche JN, Aubin JE. Determination of the capacity for proliferation and differentiation of osteoprogenitor cells in the presence and absence of dexamethasone. Dev Biol 1990; 140: 132-138.

44. Kawase T, Okuda K, Saito Y, Yoshie H. In vitro evidence that the biological effects of platelet-rich plasma on periodontal ligament cells is not mediated solely by constituent transforming-growth factor-beta or platelet-derived growth factor. J Periodontol 2005; 76: $760-767$.

45. Mosmann T. Rapid colorimetric assay for cellular growth and survival: application to proliferation and cytotoxicity assays. J Immunol Methods 1983; 65: 55-63.

46. van den Dolder J, Spauwen PH, Jansen JA. Evaluation of various seeding techniques for culturing osteogenic cells on titanium fiber mesh. Tissue Eng 2003; 9: 315-325.

47. Stein GS, Lian JB, Stein JL, Van Wijnen AJ, Montecino M. Transcriptional control of osteoblast growth and differentiation. Physiol Rev 1996; 76: 593-629.

48. Thomas DM, Johnson SA, Sims NA, Trivett MK, Slavin JL, Rubin BP, Waring P, McArthur GA, Walkley CR, Holloway AJ, Diyagama D, Grim JE, Clurman BE, Bowtell DD, Lee JS, Gutierrez GM, Piscopo DM, Carty SA, Hinds PW. Terminal osteoblast 
differentiation, mediated by runx 2 and $\mathrm{p} 27 \mathrm{KIP} 1$, is disrupted in osteosarcoma. J Cell Biol 2004; 167: 925-934.

49. Choi BH, Zhu SJ, Kim BY, Huh JY, Lee SH, Jung JH. Effect of platelet-rich plasma (PRP) concentration on the viability and proliferation of alveolar bone cells: an in vitro study. Int J Oral Maxillofac Surg 2005; 34: 420-424.

50. Gruber R, Kandler B, Fischer MB, Watzek G. Osteogenic differentiation induced by bone morphogenetic proteins can be suppressed by platelet-released supernatant in vitro. Clin Oral Implants Res 2006; 17: 188-193.

51. Tomoyasu A, Higashio K, Kanomata K, Goto M, Kodaira K, Serizawa H, Suda T, Nakamura A, Nojima J, Fukuda T, Katagiri T. Platelet-rich plasma stimulates osteoblastic differentiation in the presence of BMPs. Biochem Biophys Res Commun 2007; 361: 62-67.

52. Uggeri J, Belletti S, Guizzardi S, Poli T, Cantarelli S, Scandroglio R, Gatti R. Dosedependent effects of platelet gel releasate on activities of human osteoblasts. J Periodontol 2007; 78: 1985-1991.

53. De Oliveira PT, De Oliva MA, Maximiano WMA, Sebastião KEV, Crippa GE, Ciancaglini P, Beloti MM, Nanci A, Rosa AL. Effects of a mixture of growth factors and proteins on the development of the osteogenic phenotype in human alveolar bone cell cultures. J Histochem Cytochem 2008 Mar 31; Epub ahead of print. http://dx.doi.org/10.1369/jhc.2008.950758.

54. Tye CE, Rattray KR, Warner KJ, Gordon JA, Sodek J, Hunter GK, Goldberg HA. Delineation of the hydroxyapatite-nucleating domains of bone sialoprotein. J Biol Chem 2003; 278: 7949-7955.

55. Tye CE, Hunter GK, Goldberg HA. Identification of the type I collagen-binding domain of bone sialoprotein and characterization of the mechanism of interaction. J Biol Chem 2005; 280: 13487-13492.

56. Wennberg C, Hessle L, Lundberg P, Mauro S, Narisawa S, Lerner UH, Millán JL. Functional characterization of osteoblasts and osteoclasts from alkaline phosphatase knockout mice. J Bone Miner Res 2000; 15: 1879-1888.

57. Simão AM, Beloti MM, Rosa AL, de Oliveira PT, Granjeiro JM, Pizauro JM, Ciancaglini P. Culture of osteogenic cells from human alveolar bone: a useful source of alkaline phosphatase. Cell Biol Int 2007; 31: 1405-1413.

58. Millán JL. Mammalian alkaline phosphatases: from biology to applications in medicine and biotechnology. Weinhein: Wiley VCH; 2006. 337 pp. 
TABLE I. Quantitative analysis (mean $\pm \mathrm{SD}, n)$ of total cell number $\left(\times 10^{4}\right)$, cell viability (\%), cycling cells (\% Ki-67 positive cells), total protein content $(\mu \mathrm{g} / \mathrm{mL})$, and alkaline phosphatase (ALP) activity ( $\mu$ mol thymolphthalein $/ \mathrm{h} / \mathrm{mg}$ protein) of control and GFs+proteins treated human alveolar bone-derived osteogenic cell cultures grown on titanium discs

\begin{tabular}{lcccc}
\hline Parameters & $\begin{array}{c}\text { Time } \\
\text { points } \\
\text { (days) }\end{array}$ & Control & GFs+proteins & $\begin{array}{c}\text { Mann- } \\
\text { Whitney test }\end{array}$ \\
\hline Total cell number & 1 & $1.6 \pm 0.4(5)$ & $1.5 \pm 0.5(5)$ & $\mathrm{NS}^{\mathrm{a}}$ \\
& 4 & $6.9 \pm 0.4(5)$ & $11.1 \pm 0.5(5)$ & $\mathrm{S}^{\mathrm{b}}$ \\
Cell viability & 7 & $14.3 \pm 2.6(5)$ & $37.4 \pm 6.7(5)$ & $\mathrm{S}^{\mathrm{b}}$ \\
& 4 & $95.2 \pm 1.6(5)$ & $97.0 \pm 1.6(5)$ & $\mathrm{S}^{\mathrm{c}}$ \\
Cycling cells & 7 & $95.3 \pm 2.0(5)$ & $97.3 \pm 0.8(5)$ & $\mathrm{NS}^{\mathrm{a}}$ \\
& 1 & $71.9 \pm 1.7(3)$ & $83.8 \pm 8.6(3)$ & $\mathrm{S}^{\mathrm{d}}$ \\
Total protein content & 4 & $66.2 \pm 10.9(3)$ & $81.7 \pm 1.6(3)$ & $\mathrm{S}^{\mathrm{d}}$ \\
& 4 & $16.8 \pm 4.5(5)$ & $33.9 \pm 9.3(5)$ & $\mathrm{S}^{\mathrm{b}}$ \\
ALP activity & 10 & $90.0 \pm 6.4(5)$ & $150.4 \pm 24.5(3)$ & $\mathrm{S}^{\mathrm{b}}$ \\
& 4 & $29.8 \pm 10.1(5)$ & $9.6 \pm 2.1(5)$ & $\mathrm{S}^{\mathrm{b}}$ \\
& 7 & $43.6 \pm 9.1(5)$ & $2.8 \pm 0.2(5)$ & $\mathrm{S}^{\mathrm{b}}$ \\
\hline
\end{tabular}

${ }^{a}$ Non significant $(p>0.05)$.

${ }^{\mathrm{b}}$ Significant $(p<0.01)$.

${ }^{\mathrm{c}}$ Significant $(p<0.05)$.

${ }^{\mathrm{d}}$ Significant $(p=0.05)$. 
TABLE II. Quantitative analysis (mean $\pm \mathrm{SD}, n$ ) of MTT assay (optical density, 570-650 nm), alkaline phosphatase (ALP) activity ( $\mu$ mol thymolphthalein/h/mg protein), total protein content $(\mu \mathrm{g} / \mathrm{mL})$, and proportion of bone-like nodule formation (\%) of control, GFs + proteins, GFs + proteins/10, GFs+proteins/100, and proteins treated rat calvarial osteogenic cell cultures grown on titanium discs

\begin{tabular}{lcccccc}
\hline \multirow{2}{*}{ Groups } & $\begin{array}{c}\text { MTT } \\
\text { assay }\end{array}$ & \multicolumn{2}{c}{ ALP activity } & Total protein content & $\begin{array}{c}\text { Bone-like } \\
\text { nodule } \\
\text { formation }\end{array}$ \\
\cline { 2 - 7 } Control & Day 7 & Day 7 & Day 10 & Day 7 & Day 10 & Day 14 \\
\hline GFs+proteins & $0.12 \pm 0.01$ & $6.2 \pm 2.6$ & $24.9 \pm 5.4$ & $58.0 \pm 3.2$ & $92.6 \pm 3.4$ & $56.6 \pm 10.1$ \\
& $(4)$ & $(5)$ & $(5)$ & $(5)$ & $(5)$ & $(4)$ \\
GFs+proteins/10 & $0.20 \pm 0.02$ & $2.2 \pm 1.4$ & $2.0 \pm 0.6$ & $81.3 \pm 7.4$ & $99.0 \pm 10.1$ & $0.9 \pm 0.3$ \\
& $(4)$ & $(4)$ & $(5)$ & $(4)$ & $(5)$ & $(4)$ \\
GFs+proteins/100 & $0.13 \pm 0.01$ & $1.0 \pm 0.4$ & $5.0 \pm 1.9$ & $67.5 \pm 4.9$ & $96.0 \pm 9.1$ & $0.7 \pm 0.7$ \\
& $(4)$ & $(5)$ & $(5)$ & $(5)$ & $(5)$ & $(4)$ \\
Proteins & $0.10 \pm 0.01$ & $0.4 \pm 0.9$ & $3.4 \pm 2.0$ & $46.5 \pm 3.1$ & $73.9 \pm 5.8$ & $26.4 \pm 1.4$ \\
& $(4)$ & $(5)$ & $(5)$ & $(5)$ & $(5)$ & $(4)$ \\
Kruskal-Wallis & $0.12 \pm 0.02$ & $1.2 \pm 0.9$ & $8.6 \pm 2.1$ & $53.9 \pm 3.5$ & $87.0 \pm 11.4$ & $46.8 \pm 0.7$ \\
test & $(4)$ & $(4)$ & $(4)$ & $(4)$ & $(4)$ & $(4)$ \\
\hline
\end{tabular}

${ }^{a}$ Significant $(p<0.01)$. 
TABLE III. Comparative analysis (Fischer post-test) for MTT, alkaline phosphatase (ALP) activity, total protein content, and bone-like nodule formation of control, GFs+proteins, GFs + proteins/10, GFs + proteins/100, and proteins treated rat calvarial osteogenic cell cultures grown on titanium discs

\begin{tabular}{|c|c|c|c|c|c|c|}
\hline \multirow{2}{*}{ Comparisons (Fischer post-test) } & \multirow{2}{*}{$\begin{array}{l}\text { MTT } \\
\text { assay }\end{array}$} & \multicolumn{2}{|c|}{ ALP activity } & \multicolumn{2}{|c|}{ Total protein content } & \multirow{2}{*}{$\begin{array}{c}\text { Bone-like } \\
\text { nodule } \\
\text { formation }\end{array}$} \\
\hline & & Day 7 & Day 10 & Day 7 & Day 10 & \\
\hline Control x GFs + proteins & $1 \%$ & $5 \%$ & $0.1 \%$ & $0.1 \%$ & $\mathrm{NS}^{\mathrm{a}}$ & $0.1 \%$ \\
\hline Control x GFs + proteins $/ 10$ & $\mathrm{NS}^{\mathrm{a}}$ & $0.1 \%$ & $0.1 \%$ & $0.1 \%$ & $\mathrm{NS}^{\mathrm{a}}$ & $0.1 \%$ \\
\hline Control x GFs + proteins $/ 100$ & $\mathrm{NS}^{\mathrm{a}}$ & $0.1 \%$ & $0.1 \%$ & $0.1 \%$ & $1 \%$ & $0.1 \%$ \\
\hline Control x Proteins & $\mathrm{NS}^{\mathrm{a}}$ & $1 \%$ & $5 \%$ & $5 \%$ & $\mathrm{NS}^{\mathrm{a}}$ & $\mathrm{NS}^{\mathrm{a}}$ \\
\hline GFs + proteins $\times$ GFs + proteins $/ 10$ & $5 \%$ & $\mathrm{NS}^{\mathrm{a}}$ & $0.1 \%$ & $1 \%$ & $\mathrm{NS}^{\mathrm{a}}$ & $\mathrm{NS}^{\mathrm{a}}$ \\
\hline GFs + proteins $x$ GFs + proteins $/ 100$ & $0.1 \%$ & $1 \%$ & $5 \%$ & $0.1 \%$ & $0.1 \%$ & $1 \%$ \\
\hline GFs + proteins $x$ Proteins & $1 \%$ & $\mathrm{NS}^{\mathrm{a}}$ & $0.1 \%$ & $0.1 \%$ & $5 \%$ & $0.1 \%$ \\
\hline GFs + proteins $/ 10 \times$ GFs + proteins $/ 100$ & $1 \%$ & $\mathrm{NS}^{\mathrm{a}}$ & $\mathrm{NS}^{\mathrm{a}}$ & $0.1 \%$ & $0.1 \%$ & $0.1 \%$ \\
\hline GFs + proteins $/ 10 \times$ Proteins & $\mathrm{NS}^{\mathrm{a}}$ & $\mathrm{NS}^{\mathrm{a}}$ & $5 \%$ & $0.1 \%$ & $\mathrm{NS}^{\mathrm{a}}$ & $0.1 \%$ \\
\hline GFs + proteins $/ 100 \times$ Proteins & $5 \%$ & $\mathrm{NS}^{\mathrm{a}}$ & $0.1 \%$ & $1 \%$ & $\mathrm{NS}^{\mathrm{a}}$ & $1 \%$ \\
\hline
\end{tabular}

${ }^{\mathrm{a}}$ Non significant $(p>0.05)$. 


\section{CAPTIONS OF THE FIGURES}

Figure 1. Epifluorescence of control (A-D) and GFs+proteins treated (E-H) human alveolar bone-derived osteoblastic cell cultures grown on titanium discs at days 1 (A,E), 4 (B,F), 7 (C,G), and $14(\mathrm{D}, \mathrm{H})$. At day 1 , control and treated cells were polygonal in shape, with treated cells showing thinner cytoplasmic extensions (compare E with A). No differences were detected between control and treated cells in terms of vinculin labeling, which was mostly perinuclear and associated with focal adhesions sites (A,E, insets; red fluorescence). At days 4, 7, and 14, GFs+proteins treated cultures exhibited a higher number of cells compared to control (compare F-H with B-D). At day 14, control cultures showed focal areas of calcified matrix (D, red autofluorescence) and cell nuclei with typical morphological aspects of apoptosis (D, right inset), whereas treated cultures exhibited no signs of osteogenic phenotype $(\mathrm{H})$ and only occasional apoptotic cells (H, right inset). Only control cultures exhibited bone sialoprotein (BSP) labeling at day 14 (green fluorescence; compare D, left inset with $\mathrm{H}$, left inset), which in some areas circumscribed Alizarin red (AR, red fluorescence)-stained nodule formation (D, left inset). Green fluorescence represents actin cytoskeleton labeling for A-H (whitish for A,E insets), whereas blue fluorescence indicates cell nuclei. Scale bar: A-H $=100 \mu \mathrm{m}$; A,E insets $=50 \mu \mathrm{m}$; $\mathrm{D}, \mathrm{H}$ left insets $=200 \mu \mathrm{m} ; \mathrm{D}, \mathrm{H}$ right insets $=25 \mu \mathrm{m}$.

Figure 2. Scanning electron micrographs of control (A,B) and GFs+proteins treated (C,D) human alveolar bone-derived osteoblastic cell cultures grown on titanium discs, at days $1(\mathrm{~A}, \mathrm{C})$ and $4(\mathrm{~B}, \mathrm{D})$. At day $1, \mathrm{GFs}+$ proteins treated cultures exhibited cells with thinner cytoplasmic extensions ( $\mathrm{C}$ and $\mathrm{C}$ inset) compared to control cells (A). At day 4, a higher number of cells was clearly noticed for treated cultures (compare D with B). Scale bars: A,C $=20 \mu \mathrm{m}$; C, inset $=25$ $\mu \mathrm{m} ; \mathrm{B}, \mathrm{D}=100 \mu \mathrm{m}$. 
Figure 3. Total cell number of control and GFs+proteins treated human alveolar bone-derived osteoblastic cell cultures grown on titanium discs. At days 4 and 7 , total cell number was significantly higher $(p<0.01)$ for the treated group. Data are reported as mean \pm standard deviation $(n=5)$.

Figure 4. Double labeling Ki-67/DAPI (red and blue fluorescence, respectively) to determine the proportions of cycling cells of control $(A, B)$ and GFs+proteins treated $(C, D)$ human alveolar bone-derived osteoblastic cell cultures grown on titanium discs, at days $1(\mathrm{~A}, \mathrm{C})$ and $4(\mathrm{~B}, \mathrm{D})$. Scale bar: $A-D=50 \mu \mathrm{m}$.

Figure 5. Proportions of cycling cells of control and GFs+proteins treated human alveolar bonederived osteoblastic cell cultures grown on titanium discs. A significant enhancement $(p=0.05)$ in the proportion of cycling cells was observed for GFs + proteins treated cultures. Data are reported as mean \pm standard deviation $(n=3)$.

Figure 6. Double labeling alkaline phosphatase/DAPI (red and blue fluorescence, respectively) of control (A-C) and GFs+proteins treated (D-F) human alveolar bone-derived osteoblastic cell cultures grown on titanium discs, at days 4 (A,D), 7 (B,E), and 10 (C,F). A weak ALP labeling was clearly observed for treated cultures. Scale bar: A-F $=200 \mu \mathrm{m}$.

Figure 7. Alkaline phosphatase (ALP) activity ( $\mu \mathrm{mol}$ thymolphthalein/h/mg protein) of control and GFs+proteins treated human alveolar bone-derived osteoblastic cell cultures grown on titanium discs, at days 4, 7, and 10. Cultures exposed to GFs+proteins exhibited significantly $(\mathrm{p}<0.01)$ reduced ALP activity levels. Data are reported as mean \pm standard deviation $(n=5)$. 
Figure 8. Dual-labeled bone sialoprotein (BSP, red fluorescence)/DAPI (blue fluorescence) of control (A), proteins (B), GFs+proteins (C), GFs+proteins/10 (D), and GFs+proteins/100 (E) treated calvaria-derived osteogenic cultures grown on titanium discs for 7 days. While control cultures showed larger areas of BSP labeling mostly associated with initial cell multilayering (A), treated cultures exhibited fewer areas of BSP labeling and of weaker intensity (B-E). Note a higher cell density for GFs+proteins treated cultures (C). Scale bar: A-E $=200 \mu \mathrm{m}$.

Figure 9. Viability/proliferation analysis (MTT assay) of control, GFs+proteins, GFs + proteins/10, GFs+proteins/100, and proteins treated calvaria-derived osteogenic cultures grown on titanium discs, at day 7. Cultures exposed to GFs+proteins exhibited a higher number of viable cells. The optical density was read at $570-650 \mathrm{~nm}$ and data were expressed as absorbance.

Figure 10. Alkaline phosphatase (ALP) activity ( $\mu \mathrm{mol}$ thymolphthalein/h/mg protein) of control, GFs+proteins, GFs+proteins/10, GFs+proteins/100, and proteins treated calvaria-derived osteogenic cultures grown on titanium discs, at days 7 and 10 . Note that there was no doseresponse relationship for ALP activity at day 10. The lowest levels were observed for the GFs+proteins treated cultures, whereas no differences were detected between the 1:10 and 1:100 dilutions.

Figure 11. Total protein content $(\mu \mathrm{g} / \mathrm{mL})$ of control, GFs + proteins, GFs + proteins/10, GFs+proteins/100, and proteins treated calvaria-derived osteogenic cultures grown on titanium discs, at days 7 and 10. The graph pattern/profile matches the one for MTT assay at day 7 (compare with Figure 9). 
Figure 12. Triple-labeling bone sialoprotein (BSP, green fluorescence)/DAPI (blue fluorescence)/Alizarin red (red fluorescence) of control (A), proteins (B), GFs +proteins (C), GFs+proteins/10 (D), and GFs+proteins/100 (E) treated calvaria-derived osteogenic cultures grown on titanium discs, at day 14. Calcified bone-like nodules (A,B,E; Alizarin red stained) were only observed for control, proteins and GFs+proteins/100 groups, which also exhibited BSP labeling (green fluorescence). No Alizarin red staining and BSP labeling was detected for GFs+proteins and GFs+proteins/10 groups (C and D, respectively). Scale bar: A,B,E $=100 \mu \mathrm{m}$; $\mathrm{C}, \mathrm{D}=200 \mu \mathrm{m}$.

Figure 13. Macroscopic imaging and quantitative analysis of Alizarin red stained areas for control, GFs+proteins, GFs+proteins/10, GFs+proteins/100, and proteins treated calvaria-derived osteogenic cultures grown on titanium discs, at day 14. The percentage of total area occupied by stained regions was significantly higher for control and proteins group. While a complete lack of bone-like nodule formation was clearly noticed for the GFs+proteins and GFs+proteins/10 groups, GFs+proteins/100 supported the development of the osteogenic phenotype. Titanium disc diameter $=12 \mathrm{~mm}$. 


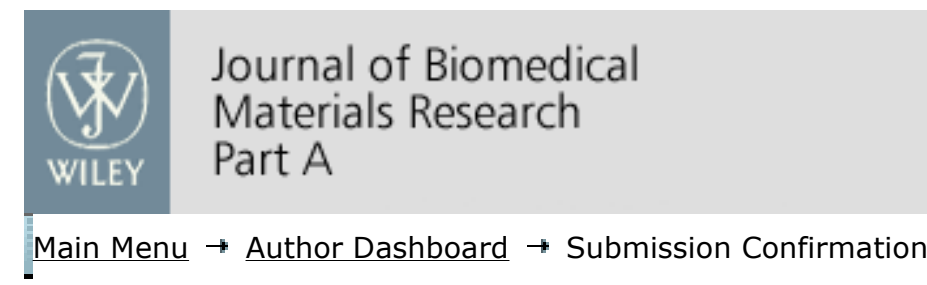

Edit Account | Instructions \& Forms | Log Out |

\section{Submission}

\section{Confirmation}

Thank you for submitting your manuscript to Journal of Biomedical Materials Research: Part A.

Manuscript ID: JBMR-A-08-0379

Title: Treatment with a Growth Factor-Protein Mixture Inhibits Formation of Mineralized Osteogenic Cell Cultures Grown on Titanium

de Oliva, Marcos

Maximiano, William

de Castro, Larissa

da Silva Junior, Paulo

Authors: Fernandes, Roger

Ciancaglini, Pietro

Beloti, Márcio

Nanci, Antonio

Rosa, Adalberto L.

Tambasco de Oliveira, Paulo

Date Submitted: 02-May-2008

\footnotetext{
Manuscript Central ${ }^{\mathrm{TM}}$ v4.10 (patent \#7,257,767 and \#7,263,655). (c) ScholarOne, Inc., 2007. All Rights Reserved. Manuscript Central is a trademark of ScholarOne, Inc. ScholarOne is a registered trademark of ScholarOne, Inc. Terms and Conditions of Use - ScholarOne Privacy Policy
} 